Article

\title{
New Approach to Assess Multi-Scale Coastal Landscape Vulnerability to Erosion in Tropical Storms in Vietnam
}

\author{
Cao Huan Nguyen ${ }^{1}$, Kinh Bac Dang ${ }^{1, *} \mathbb{D}$, Van Liem Ngo ${ }^{1} \mathbb{D}$, Van Bao Dang ${ }^{1}$, Quang Hai Truong ${ }^{2}$, \\ Dang Hoi Nguyen ${ }^{3}$, Tuan Linh Giang ${ }^{4}$, Thi Phuong Nga Pham ${ }^{1}$, Chi Cuong Ngo ${ }^{1}$, Thi Thuy Hoang ${ }^{1}$ \\ and Thi Ngoc Dang ${ }^{1}$
}

1 Faculty of Geography, VNU University of Science, Vietnam National University, Hanoi, 334 Nguyen Trai, Thanh Xuan, Hanoi 100000, Vietnam; nguyencaohuan@hus.edu.vn (C.H.N.); liemnv@hus.edu.vn (V.L.N.); dangvanbao@hus.edu.vn (V.B.D.); Ngaptp@hus.edu.vn (T.P.N.P.); cuong95.hus@gmail.com (C.C.N.); hoangthuy.hus@gmail.com (T.T.H.); dangthingoc@hus.edu.vn (T.N.D.)

2 VNU Institute of Vietnamese Studies and Development Sciences, Vietnam National University, Hanoi, 336 Nguyen Trai, Hanoi 100000, Vietnam; haitq.ivides@gmail.com

3 Vietnam-Russian Tropical Centre, Institute of Tropical Ecology, 63 Nguyen Van Huyen, Hanoi 100000, Vietnam; danghoi110@gmail.com

4 SKYMAP High Technology Co., Ltd., No.6, 40/2/1, Ta Quang Buu, Hai Ba Trung, Hanoi 100000, Vietnam; linh.gt@eofactory.ai

* Correspondence: dangkinhbac@hus.edu.vn

check for updates

Citation: Nguyen, C.H.; Dang, K.B.; Ngo, V.L.; Dang, V.B.; Truong, Q.H.; Nguyen, D.H.; Giang, T.L.; Pham, T.P.N.; Ngo, C.C.; Hoang, T.T.; et al. New Approach to Assess Multi-Scale Coastal Landscape Vulnerability to

Erosion in Tropical Storms in

Vietnam. Sustainability 2021, 13, 1004 https://doi.org/10.3390/su13021004

Received: 23 November 2020

Accepted: 15 January 2021

Published: 19 January 2021

Publisher's Note: MDPI stays neutral with regard to jurisdictional claims in published maps and institutional affiliations.

Copyright: (c) 2021 by the authors. Licensee MDPI, Basel, Switzerland. This article is an open access article distributed under the terms and conditions of the Creative Commons Attribution (CC BY) license (https:// creativecommons.org/licenses/by/ $4.0 /)$.

\begin{abstract}
The increase of coastal erosion due to intense tropical storms and unsustainable urban development in Vietnam demands vulnerability assessments at different research scales. This study proposes (1) a new approach to classify coastlines and (2) suitable criteria to evaluate coastal vulnerability index (CVI) at national and regional/local scales. At the national scale, the Vietnamese coastline was separated into 72 cells from 8 coast types based on natural features, whereas the Center region of Vietnam was separated into 495 cells from 41 coast types based on both natural and socio-economic features. The assessments were carried out by using 17 criteria related to local land use/cover, socio-economic, and natural datasets. Some simplified variables for CVI calculation at the national scale were replaced by quantitative variables at regional/local scales, particularly geomorphology and socio-economic variables. As a result, more than $20 \%$ of Vietnam's coastline has high CVI values, significantly more than $350 \mathrm{~km}$ of the coasts in the center part. The coastal landscapes with residential and tourism lands close to the beaches without protection forests have been strongly affected by storms' erosion. The new approach is cost-effective in data use and processing and is ideal for identifying and evaluating the CVI index at different scales.
\end{abstract}

Keywords: coastal vulnerability index; coastal characteristic; coastal forcing; socio-economic characteristic; national scale; regional scale; local scale

\section{Introduction}

Coastal zones are essential for 600 million people globally living in coastal lowland areas and are the most productive and regular human activity areas [1-4]. In recent years, global and local climate change has increased the frequency and intensity of extreme natural hazards on coasts, especially with erosion due to tropical storms and sea-level rise [5-8]. Globally, 70\% of beaches have been eroded [8,9]. The area of eroded coasts worldwide increased by 28,000 $\mathrm{km}^{2}$ from 1984 to 2015 [10]. In Vietnam, the coastline changes were found on approximately $920.21 \mathrm{~km} \mathrm{[11].} \mathrm{According} \mathrm{to} \mathrm{Reference} \mathrm{[11],} \mathrm{over}$ the past few years, the coast of Vietnam lost about 1480 ha in the northern part (from Quang Ninh to Ninh Binh) due to erosion, about 9758 ha in the central region, and about 13,690 ha in the southern part. Under the pressure of socio-economic development, especially coastal tourism in the last ten years, coastal erosion has caused significant damage to coastal people's livelihoods $[12,13]$. Despite no casualties, coastal erosion has caused a lot 
of property damage, equivalent to $1.5 \%$ of annual Gross Domestic Product (GDP) [14-17]. Every year, the Vietnamese government spends hundreds of billions VND to renovate dykes to prevent coastal erosion [18]. Many tourist sites have been built close to the sea of Quang Nam and Thua Thien Hue provinces, reducing the area of coastal protective forests and leading to the increase of the erosion to more than about 15-20 m/year [19].

The "coastal erosion" topic in Vietnam has caught researchers' attention since the 1990s. The studies mainly used hydrodynamic morphodynamical methods, remote sensing, and Geographic Information System (GIS) to observe/predict coastlines' changes. Some studies analyzed the coastal erosion at the national scale [11,20-23], to regional scale [24-26], and in more detail for small areas $[19,27,28]$. However, most of the research only studied the current status, causes, and speed of coastline fluctuations (erosion and deposition) and predicted the trend of erosion due to global climate change (concerning the sea-level rise and storm surge) [29]. The research about the coastal effects of erosion on coastal landscapes is rare.

The coastal vulnerability index (CVI) has been used to assess the vulnerability of a coastal area to coastal erosion and storm surge [24,30-33]. In this way, it is a common tool that contributes to decision-making in the sustainable use of coastal resources, the planning of development projects, and integrated coastal management [34,35]. According to Intergovernmental Panel on Climate Change (IPCC), the CVI is affected by three main criteria groups, including exposure, sensitivity, and adaptive capacity of coasts under climate changes [36]. In which, the adaptive capacity of the coasts contains modification to mitigate damages caused by climate changes and take full advantage of positive impacts of climate changes. The main challenge to assess coastal vulnerability is data scarcity, that is dependent on the number of input criteria. Accordingly, the authors of Reference [37] used about 43 criteria to investigate the coastal dune vulnerability, while Reference [30] used six criteria to identify vulnerable areas due to erosion at national scales. The climatic and hydrological characteristics are commonly homogeneous in a long coastline. As another example, the use of criteria "population" or its density is collected at administrative units [38]. These criteria used for CVI assessments are similar from national to regional scales. Therefore, data generalization at national scales can reduce the accuracy of the CVI calculation at the regional scale. It is necessary to provide more detailed data at regional/local scales related to distribution of protection forests and population, as well as economic development along the coasts, to better assess damages under the impact of waves and storm surge.

A few studies assessed the coastal vulnerability in Vietnam due to the effects of climate change and sea level rise. However, the criteria used for the CVI assessments is varied. For instance, the authors of Reference [39] calculated the CVI for the coastal zone of the Ba Lat estuary area with three groups of factors: vulnerability factors (e.g., erosion, typhoons, channel siltation, sea-level rise, environmental pollution, and hazards intensifying factors-natural and human activities), vulnerable objects (e.g., wetland resources and human works), and resilience of socio-ecological system (e.g., education, health facilities, communication, and transportation). The authors of References $[12,40]$ estimated the natural CVI for the southern area of Vietnam, with the use of six parameters, including (a) geomorphology, (b) slope (\%), (c) sea-level rise rate (mm/year), (d) rate of coastline change or accretion/erosion (m/year), (e) tidal height $(\mathrm{m})$, and (f) mean wave height $(\mathrm{m})$. The authors of Reference [41] used the number of storms and tropical depressions together with the wave height values during storms to assess the coastal vulnerability in Vietnam. The authors of Reference [15] emphasized the effects of the unsustainable development in coastal cities, leading to the significant increase of damage in Vietnam's coastal zone. The authors of Reference [27] used three components of exposure, sensitivity, and adaptability, and 48 related indicators, to assess vulnerability due to climate change in lagoons of Thua Thien Hue province, and some coastal communes in Quang Binh and Quang Tri provinces.

In this study, various methods were harnessed to provide the primary input data for coastal vulnerability assessments. The classification of coastal landscapes at the national 
scale was assembled by a developed machine learning model based on coastal geomorphological data, hydrological data, and remote sensing data, whereas the coastal landscapes at the regional scale were classified based on the distribution of land uses/covers from coastline to inland areas. All required coastal characteristics, tidal, storm, erosion, and socio-economic data, to calculate CVI index were integrated into a coastal Geographical Information System (coastal GIS) [42-44]. The overall aim of this research was (1) to provide the best criteria tables to assess coastal vulnerability due to erosion at the national and regional scales, and (2) to calculate CVI index in different landscape types in Vietnam and the Central Vietnam. This study addresses the interactions between coastal characteristics, coastal forcing, and socio-economic conditions under the effects of erosion during extreme climate events. The assessments can provide a better understanding about Vietnamese coasts and impacts of erosion in extreme storms on coastal people. Such information can be useful for decision-making processes in coastal landscapes.

The following research questions - relevant to evaluate the CVI index due to erosionguided this study:

- Is it feasible to use coastal landscape classification systems for CVI assessments at national and regional scales?

- How is the selection of CVI assessment criteria at national and regional scales different?

- How vulnerable are the coasts in Vietnam and Central Vietnam to erosion in storms?

In the following sections, background information on the CVI index, coastal classification in Vietnam, and natural and socio-economic conditions in the Vietnamese coastal area will be introduced. The methods to calculate the CVI index and classify coasts used at national and regional scales are explained separately in Section 2.2. The coastal vulnerability assessment criterion are introduced in Section 2.3. At the end of the paper, limitations of the coastal vulnerability approach, the input data, and the calculation process are discussed. In this study, the coastal vulnerability was assessed in the $2 \mathrm{~km}$ area from coastline to inland, where it is significantly affected by erosion due to tropical storms. Adapted from Reference [45], the coasts at national and regional scales are divided into different coastal cells (shown in Section 2.2). Accordingly, a coastal cell is a littoral region along coasts containing a complete sedimentation cycle such as sinking, transporting, and eroding coastal sediments. The boundary of cells is the geographical regions where the sediment's budget is balanced. Therefore, it provides a suitable framework to quantitatively assess coastal erosion and accretion.

\section{Materials and Methods}

\subsection{Case Study}

The coastal zone of Vietnam has a coastline of over $3260 \mathrm{~km}$, from Tra Co (Mong Cai, Quang Ninh), through Ca Mau cape (at the southern end) to Ha Tien (Kien Giang), passing through 28 provinces/cities with 125 coastal districts [46,47] (Figure 1). In terms of the geological structure, tectonic form, and topographic morphology, its intra-tropical coastal zone lies neatly in the West Coast of the East Sea [18]. The climate in the coastal zone of Vietnam clearly reflects the humid monsoon tropical climate, strongly influenced by storms and monsoons, with high temperatures and high humidity. The national tidal regime is diverse, with all four known tides globally: regular and irregular diurnal tides, regular and irregular semi-diurnal tides, of which irregular diurnal tide is the most common (accounting for $51 \%$ of national coastlines) [48]. The coastal wave regime depends on the wind regime, barometric pressure, tidal waves, topography, and shore, island, and seabed. Based on the manifestations of the climate, Vietnam can be divided into two major climatic regions: (i) The North (the north of Hai Van pass) has a tropical monsoon climate, with 4 seasons (namely spring, summer, autumn, winter), and (ii) The South (the south of Hai Van pass) has a tropical climate, with warm temperatures in two distinct seasons (dry and rainy seasons). Every year, the Vietnamese coasts suffer from 5-6 storms and 2-3 tropical depressions [49]. 


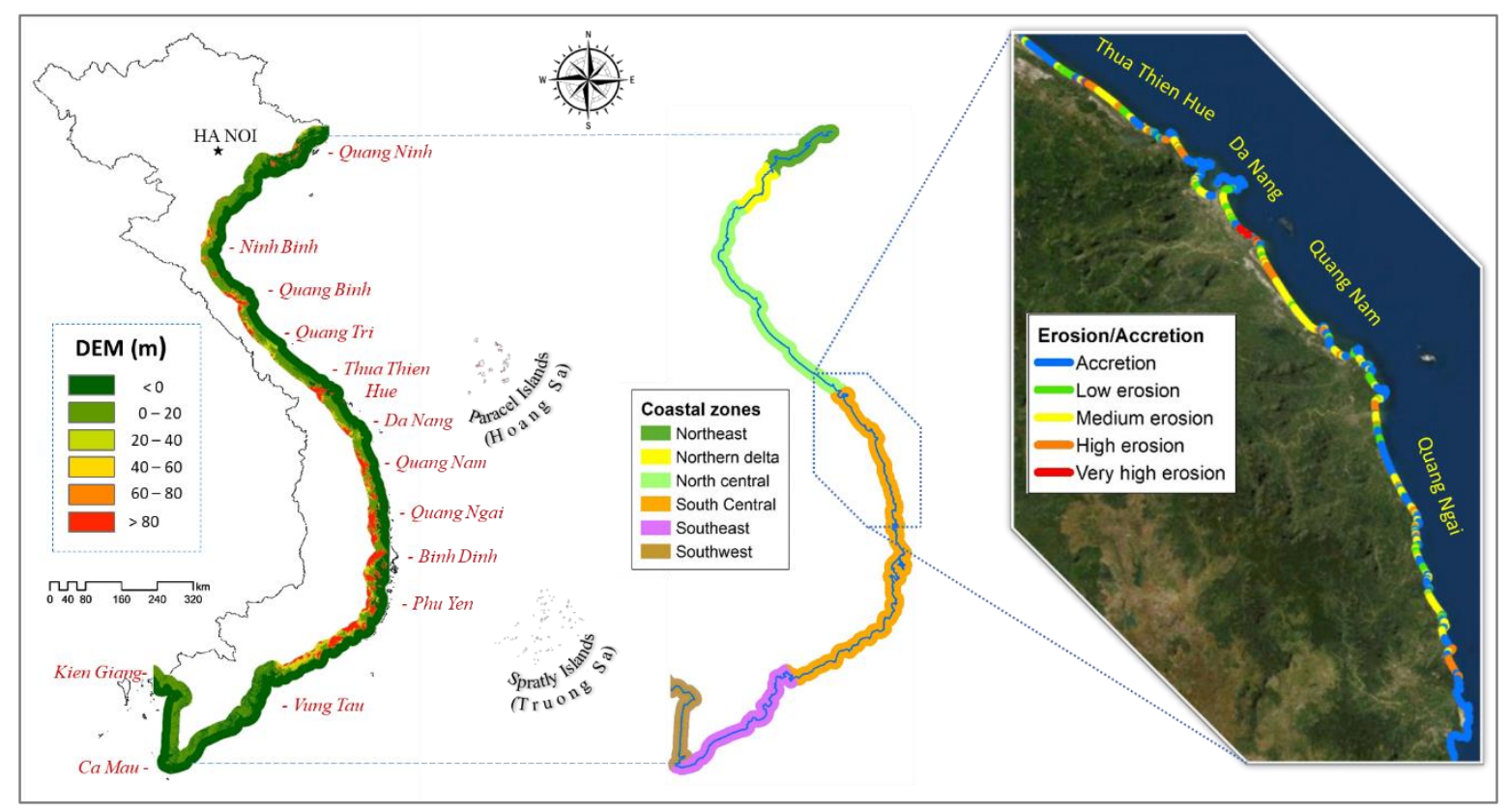

Figure 1. Research areas at national and regional scales.

The coast of Vietnam is densely populated, with many developed cities and industries. Various anthropogenic landscapes and famous tourist beaches scatter along the coast of Vietnam. Besides, the coastal zone of Vietnam is also an area with the diversity and richness of natural resources such as mangroves, with great potential for economic development, ecotourism, and aquaculture [28,50]. The coastal strip is rich in mineral resources, diverse in sand mines, building materials, and exceptionally large reserves of glass sand. Various geomorphological heritage such as archaeological sites, strata, or geomorphologic landscapes with unique terrain types in limestone landscapes in Ha Long Bay, Hon Chong (Nha Trang), and basalt cliff landscapes such as Ghenh Da Dia (Phu Yen), and Ghenh Yen (Quang Ngai), have created natural resources for tourism development, the construction of deep-water seaports, and military works for security and defense protection such as ports of Da Nang, Cam Ranh, and Vung Tau [51].

The central key economic region is the dynamic economic region in Central Vietnam, including five provinces: Thua Thien-Hue, Da Nang, Quang Nam, Quang Ngai, and Binh Dinh. This region is the third largest economic region in Vietnam. This region is characterized by integrated seaport economic zones. This area has a coastline stretching for about $600 \mathrm{~km}$ and is characterized by complicated topography and geological features. Between the protruding points composed of intrusive rocks, eruptive rocks (basalt), and associated sedimentary rocks are the shores/banks composed of quaternary sedimentary rocks with a different grain size composition, from rough to smooth. The estuarine areas have developed a lagoon system with mainly sand mixed with silt and clay $[52,53]$.

The study area is located in two climatic zones, with the boundary of Hai Van pass. From Hai Van Pass to the north, in the climate of North Vietnam with tropical monsoon climate, the annual average temperature is about $25-26.9^{\circ} \mathrm{C}$. From Hai Van Pass to the south, it belongs to South Vietnam's climatic zone, with the temperature tending to increase southward, the average value is about $26^{\circ} \mathrm{C}$. While the north has irregular semi-diurnal tide, the south has irregular diurnal tide with amplitude from 0.5 to $2.0 \mathrm{~m} \mathrm{[11].} \mathrm{In} \mathrm{winter,}$ the prevailing wave direction is Northeast direction, with the average wave height from 0.8 to $1 \mathrm{~m}$. The maximum wave height is $3-4 \mathrm{~m}$. In summer, the dominant wave is the South-West, with the average wave height from 0.6 to $1.1 \mathrm{~m}$, and the maximum wave height is $2-3.5 \mathrm{~m}$ [11].

The central key economic region is an area with the distribution of valuable important marine ecosystems such as coral reefs, seagrass beds, and recognized international 
biosphere reserves such as Biosphere Reserve Cu Lao Cham-Hoi An. However, the coastal strip from Thua Thien Hue to Binh Dinh is also a place that has suffered significant damages due to natural disasters, typically coastal erosion, storms, floods, sea-level rise, and even tsunami caused by earthquakes in the East Sea $[19,49]$. In recent years, coastal erosion activities in Thuan An (Thua Thien Hue) and Cua Dai (Hoi An, Quang Nam) have caused considerable damage to the local people.

\subsection{Multi-Scale Coastal Landscape Classification}

\subsubsection{Coastal Landscape Classification at National Scale}

In the study "A Convolutional Neural Network for coastal classification based on ALOS and NOAA satellite data" by the authors published in 2020 [46], the coastline of Vietnam was divided into 72 coastal cells based on four geomorphological features, including absolute digital elevation models (DEM), relative DEM, slope, and flow length. In which, the feature "flow length" describes the most prolonged downslope duration along the flow line, or the concentration time of water from each cell to a particular sink/outlet $[54,55]$. That coastal classification was computerized as a new feature of this study. The main objective of the study is to train the machine to understand the differences in 8 types of coastline structures, including: (1) delta coastline, (2) alluvial flats, (3) sand banks, (4) accumulation coasts, (5) lagoon coasts-bays, (6) abrasive coasts, (7) tectonic coasts, and (8) bio-biochemical origin coasts, based on the "Convolutional Neural Network" (CNN) model [56]. Through topographic data extracted from Advanced Land Observation Satellite (ALOS) and National Oceanic and Atmospheric Administration (NOAA) image data, 2400 slices characterize four topographic and hydrological parameters (including elevation, slope, depth of cleavage, and flow length) at 800 locations, and the coastlines were drawn automatically in the $700 \times 700$-pixel images (Figure 2). Each littoral cell of the coast is $10 \mathrm{~km}$ long ( $5 \mathrm{~km}$ inland and $5 \mathrm{~km}$ offshore). Eight hundred coastal cells of Vietnam were selected during the field survey and description of previous studies (such as References [11,18,57]). These cells were also the input data for the CNN machine learning model. When the machine learning model understood the differences between the four geomorphologic features among the eight coastline types, the model could classify new slices with similar features. The entire model development was done in the Python programming language $[58,59]$.

The completed CNN model classified 1150 new coasts along the Vietnamese coast with an accuracy of $98 \%$. Accordingly, $89 \%$ of the Vietnamese coastline was classified into eight types of coastline, while $11 \%$ of the coast was considered to be the ninth coastal group, also known as transitional coast or a mixture of 8 types of coastlines mentioned above. According to the geomorphological characteristics, remote sensing analysis, and field works, the transitional coasts were commonly found between two defined coastal types. For example, these undefined cut-lines mainly located in the transitional zones between clear lagoon or accumulative coasts. These cut-lines cannot be defined as a lagoon or accumulative coasts. In both defined coast types, coastal dunes along the coastline have an average elevation of 20-30 m and rivers/lakes are behind dunes. Meanwhile, the transitional coasts contain the dunes with lower elevation and more narrow rivers/lakes behind dunes. It is challenging to select a suitable type for these coasts. Therefore, the ninth coastal type named "transitional coasts" was added. Accordingly, $3260 \mathrm{~km}$ of the Vietnam coastline was divided into 72 cells, with the predominant coastline characteristics [46]. From north to south, the northern coastal strip was divided into 15 cells with three dominant coastlines, including tectonic coasts, biochemical origin coasts (or karst coasts), and delta coasts. The North Central Coast was divided into 15 cells of coastline with 3 predominant coastlines, including alluvial flats, abrasive coasts, and sandy coasts. The South-Central Coast was divided into 27 coastlines, in which there are mainly abrasive coasts, followed by accumulation coasts and sand banks. The Southern coastal strip was divided into ten cells of the coast with deltas and abrasive coasts. The results of this study detailed the previous qualitative descriptions of geological-geomorphology scientists in the field of 
natural coastal zoning [57]. However, the study just stopped at analyzing four geological features, geomorphology and hydrology, and did not go into in-depth research on the field cover and the biodiversity level above the surface.

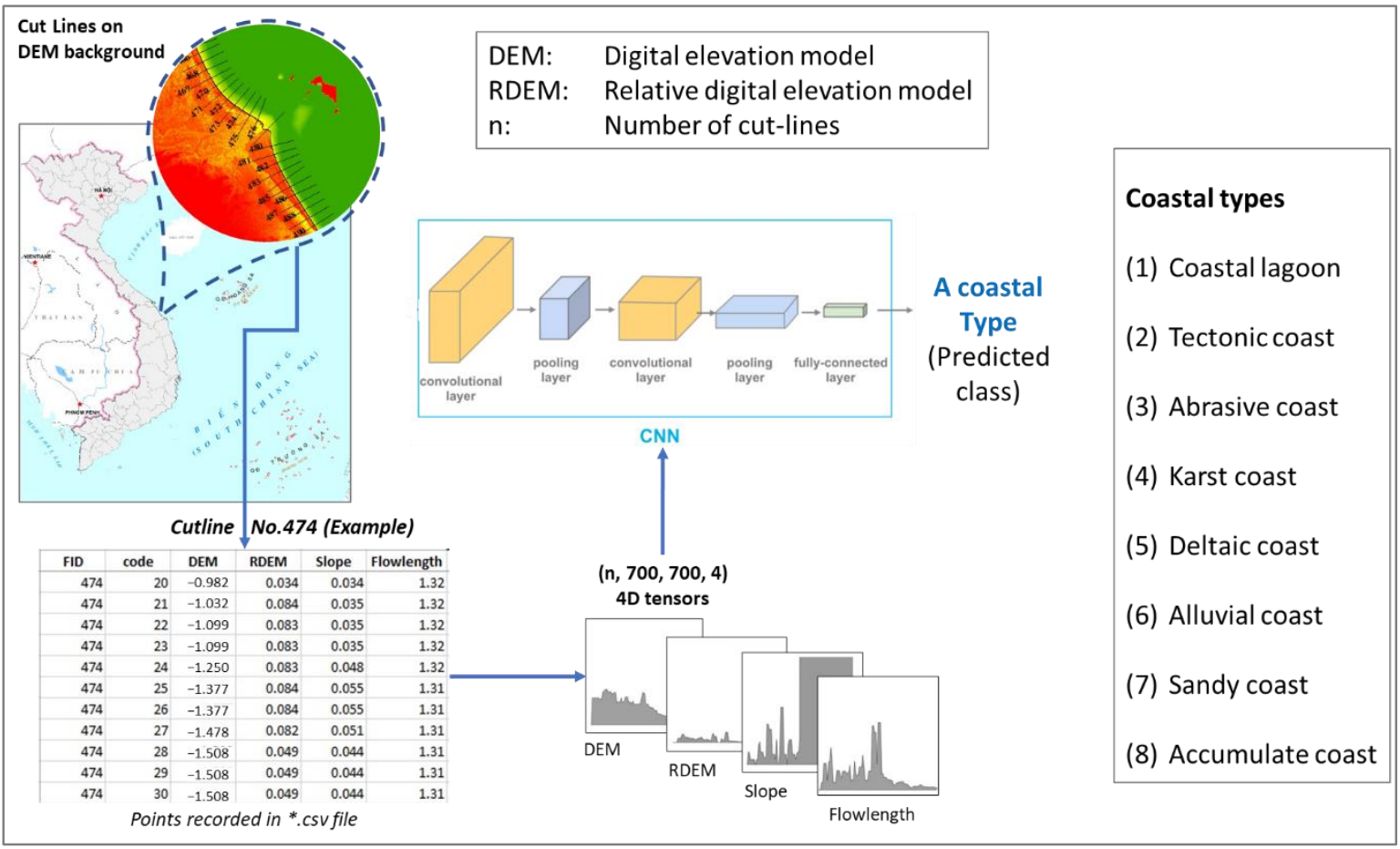

Figure 2. Steps to use the Convolutional Neural Network (CNN) model for coastal classification based on cut-lines to coastlines. As an example, in the cut-line No.474, the "code" column contains the points' range coded from [1, 101] corresponding to 101 points made in the cut-line. 800 cut-lines were generated for eight coastal types during the model development process. The CNN model learned four geomorphic characteristics of eight coast types. The accuracy of the model reaches $98 \%$ (modified from Reference [46]).

\subsubsection{Coastal Landscape Classification at a Regional Scale}

The coastline division in detail is a subject of debate not only in the marine science discipline, but also in the multidisciplinary one. In this study, the coastal type in the central key area was divided by four main groups of criteria, including: (1) geologygeomorphology, (2) dominant land covers and land uses, (3) coastal people's livelihood activities, and (4) the location of the population distributed along the coast. These four criteria were selected to represent all the natural coastal features, including petrographic composition, topography, soil, materials, exogenous effects, and human activities (Figure 3). Accordingly, 495 coastal cells in the Central part of Vietnam are divided by 41 different coastal landscape types, as shown in Table 1.

Firstly, the criteria for the classification of the coastal type according to geological and geomorphological characteristics-as divided for the entire coast of Vietnam as mentioned in Section 2.2.1-were prioritized to classify the natural coast into three main groups, including coastal sandy, cliff, and estuarine landscapes. (a) The sandy landscapes typically have a slope of less than $10 \%$, averaging about $3 \%$, and beach widths range from 20 to over $100 \mathrm{~m}$ [60]. The condition of waves can create wide sand bars that run parallel to the coast. Fine-grained sand comprises mainly of the sediment composition, forming embryo dunes and foredunes. (b) The cliff landscapes have a steep slope from $30 \%$ to $50 \%$, are composed of intrusive rocks of Kreta and Kainozoi, and do not form a coastal sand strip [57]. Narrow sandbanks which are located between the rocky coasts and have accumulated sedimentary material from the sea are also considered in the cliff landscapes. The steep rocky cliffs distribute behind these sandbanks. (c) Estuary landscapes are the transition of material 
from the mainland to the sea, with a high degree of topographic variation depending on river flow, waves, and tides $[49,61]$. Depending on the dynamics of flow from the ocean or continent, the estuary topography has both deposition and erosion properties; therefore, it is different from sandy and rocky shores, which are only affected by waves. In particular, in some areas, the sedimentation of longshore waves and coastal alluvium accumulate in front of river mouths, creating wide sand bars. Many sand bar landscapes were generated in a period of long-term stability, creating stable conditions for people to live [50].

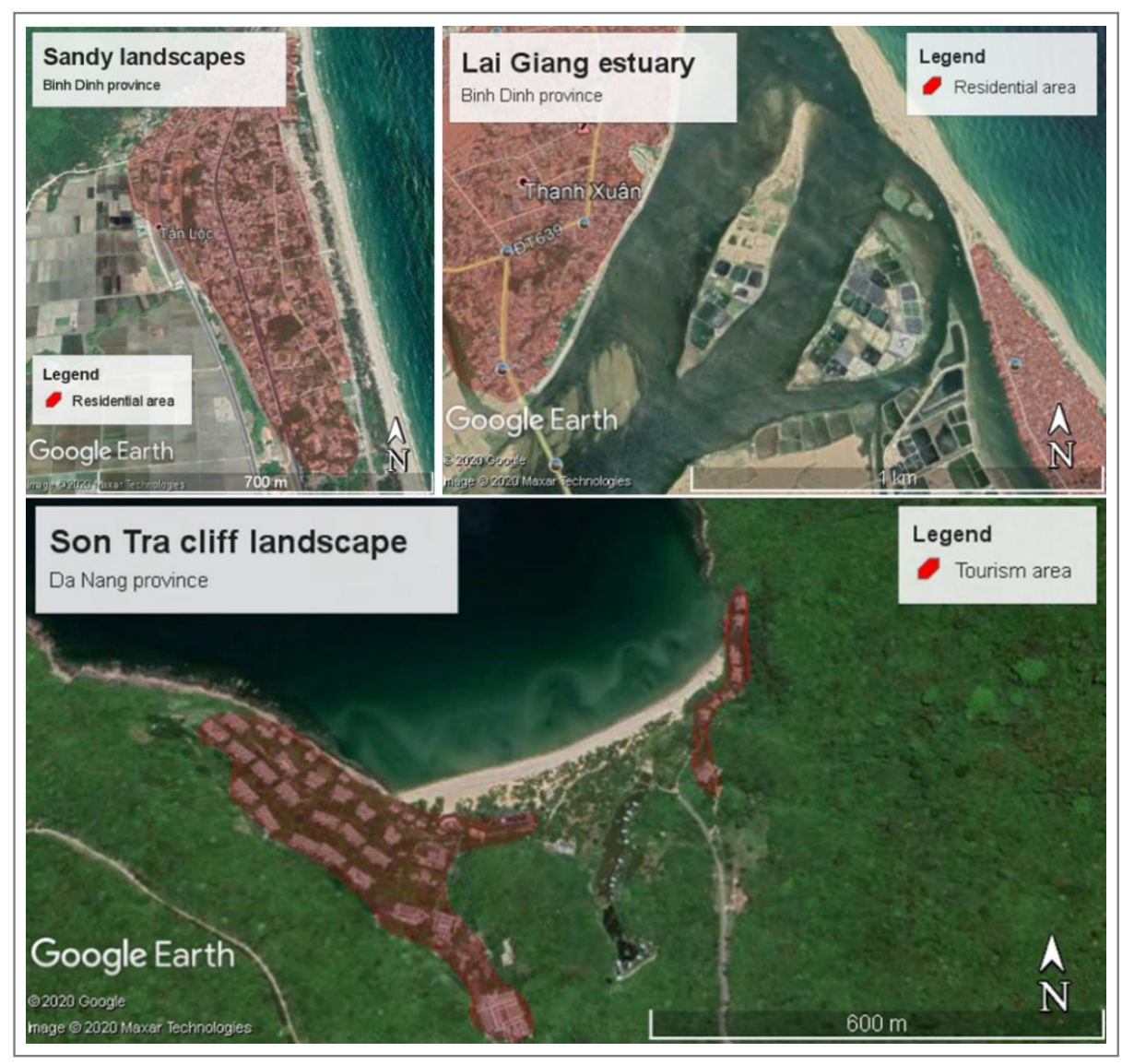

Figure 3. Distribution of anthropogenic and natural land covers in three groups of coastal landscapes.

Table 1. Coastal landscape classification for the coastal cells from Thua Thien Hue to Binh Dinh province.

\begin{tabular}{cl}
\hline Code & \multicolumn{1}{c}{ Coastal Landscape Type } \\
\hline & \multicolumn{1}{c}{ A. Natural Coastal Landscapes } \\
\hline \multicolumn{1}{c}{ A1. Sandy Landscapes } \\
\hline 1.1 & Coastal protection forest landscapes (Width of $\mathbf{1 5 0} \mathbf{~ m}$ ) \\
1.1 .1 & Highly dense protection forest landscapes \\
1.1 .2 & Medium protection forest landscapes (new planting) \\
1.1 .3 & Low protection forest landscapes (shrubs, weeds) \\
1.2 & Coasts of aquacultural and other agricultural landscapes \\
1.2 .2 & Coastal aquacultural landscapes behind $<20$ m width protection forest \\
1.2 .3 & Coastal aquacultural landscapes behind $>20$ m width protection forest \\
$\mathbf{1 . 3}$ & Coastal other agricultural landscapes \\
1.3 .1 & Coastal urban landscapes close to sea (protection construction was built) \\
1.3 .2 & Coastal rural landscapes close to sea \\
1.3 .3 & Coastal rural landscapes behind $<50$ m width protection forest \\
\hline
\end{tabular}


Table 1. Cont.

\begin{tabular}{|c|c|}
\hline Code & Coastal Landscape Type \\
\hline \multicolumn{2}{|r|}{ A. Natural Coastal Landscapes } \\
\hline \multicolumn{2}{|r|}{ A1. Sandy Landscapes } \\
\hline 1.3.4 & Coastal rural landscapes behind $50-100 \mathrm{~m}$ width protection forest \\
\hline 1.3 .5 & Coastal rural landscapes behind $>100 \mathrm{~m}$ width protection forest \\
\hline 1.4 & Coasts of construction and tourism landscapes close to sea \\
\hline 1.4.1 & Tourism coast landscapes with $>2000$ m long along sea \\
\hline 1.4 .2 & Tourism coast landscapes with $<2000 \mathrm{~m}$ long along sea \\
\hline 1.4 .3 & Sandy coast landscapes of industrial, port and special-use purposes \\
\hline \multicolumn{2}{|r|}{ A2. Cliff Landscapes } \\
\hline 2.1 & Coasts of forest cliff landscapes \\
\hline 2.1.1 & Special-use forest cliff landscapes \\
\hline 2.1.2 & Protection forest cliff landscapes \\
\hline 2.1.3 & Production forest cliff landscapes \\
\hline 2.1.4 & Rocky/sparse-vegetated cliff landscapes \\
\hline 2.2 & Coastal cliffs of rural and agricultural landscapes \\
\hline 2.2.1 & Coastal cliffs of rural landscapes \\
\hline 2.2 .2 & Coastal cliffs of aquacultural and agricultural landscapes \\
\hline 2.3 & Coastal cliffs of construction and tourism landscapes \\
\hline 2.3.1 & Coastal cliffs of construction and port \\
\hline 2.3 .2 & Coastal cliffs of stable tourism landscapes (constructed) \\
\hline 2.3.3 & Coastal cliffs of tourism landscapes (under construction) \\
\hline 2.4 & Sandy landscapes between coastal cliffs \\
\hline 2.4.1 & Natural forest and sandy landscapes between coastal cliffs \\
\hline 2.4 .2 & Sandy landscapes between coastal cliffs used for aquacultural and agricultural activities \\
\hline 2.4 .3 & Sandy landscapes between coastal cliffs used for rural development \\
\hline 2.4 .4 & Sandy landscapes between coastal cliffs used for tourism development \\
\hline \multicolumn{2}{|r|}{ A3. Estuary Landscapes } \\
\hline 3.1 & Unstable sand-bar and estuary landscapes \\
\hline 3.1.1 & Permanent estuary landscapes \\
\hline 3.1 .2 & Embryo sand-bar landscapes (without vegetation) \\
\hline 3.1 .3 & Foredune sand-bar landscapes (sparse vegetation) \\
\hline 3.1 .4 & Unstable sand-bar landscapes used for aquacultural activities \\
\hline 3.2 & Stable estuarial sand-bar landscapes used for rural and agricultural development \\
\hline 3.2.1 & Rural landscapes in stable sand-bars, close to sea \\
\hline 3.2 .2 & Rural landscapes in stable sand-bars, behind $<50 \mathrm{~m}$ width protection forest \\
\hline 3.2 .3 & Rural landscapes in stable sand-bars, behind $50-100 \mathrm{~m}$ width protection forest \\
\hline 3.2.4 & Rural landscapes in stable sand-bars, behind $>100 \mathrm{~m}$ width protection forest \\
\hline 3.3 & Stable estuary sand-bar landscapes for tourism and other constructions \\
\hline 3.3.3 & Stable estuary sand-bar landscapes for tourism \\
\hline 3.3 .4 & Stable estuary sand-bar landscapes for industrial, port and special-use purposes \\
\hline \multicolumn{2}{|r|}{ B. Anthropogenic Coastal Landscapes } \\
\hline \multicolumn{2}{|r|}{ B1. Anthropogenic Coastal Landscapes without a Beach } \\
\hline B1.1 & Anthropogenic coastal landscapes for urban development \\
\hline B1.2 & Anthropogenic coastal landscapes for industrial, port and special-use purposes \\
\hline B1.3 & Anthropogenic coastal landscapes for tourism development \\
\hline & B2. Anthropogenic Coastal Landscapes with Beaches \\
\hline
\end{tabular}

The second criterion considered in the coastal landscape classification is the predominant coastal land use/cover types. In order to assess the value of coastal ecosystems for indigenous people, the researchers divided land-use into four main groups, including (i) forest land, (ii) land used for aquaculture and other agricultural activities, (iii) coastal residential land, and (iv) land used for construction works and seaside resorts. In each of these land use types, the authors detail each land use type depending on land covering and 
the livelihood characteristics of coastal residents-the third criterion in the classification of coastal landscape types. The local coastal landscapes are explained in detail in Table 1. For example, forest cover was split into forests of high, low, and very low cover (on the sandy coasts), or by the forest's function as protection, special use, and production. Regarding the livelihoods of coastal residents, residential land was divided according to the purpose of using for agricultural, industrial, wharf, or tourism development. The inclusion of criteria 2 and 3 in the coastal landscape classification in this study was to evaluate the loss of economic benefits under the impact of waves and storm surge. Coastal areas with livelihood activities under the influence of coastal natural disasters always make the coastal vulnerability level increase.

Lastly, the location of people's settlement and economic development points for coastal protection works determines whether they are directly or indirectly vulnerable to coastal erosion. Through field surveys, indigenous people living along the coast of Vietnam have a habit of adapting to the effects of waves and storms. Houses and livelihood activities are always placed behind at least one or a few rows of coastal protection trees, such as casuarina trees-corresponding to a width of 50 to $150 \mathrm{~m}$ from the sea to the mainland (Figure 3). Especially in the Central coast areas, many populated areas are close to the coast (or the protection forest width is less than $20 \mathrm{~m}$ ) [50]. When the coastal protection forest system is completely destroyed, people are directly affected by waves, wind, and storm surges, which often happen from September to November every year. Through interviews with coastal residents, the research team found that the residential area behind the trees with a width of less than $50 \mathrm{~m}$ was affected by sea-level rise and wind during high storms. In particular, only extreme storms of the century can deeply affect people living within a radius of 50 to $100 \mathrm{~m}$ inland [62-64]. Therefore, the maximum impact limit of coastal waves and storms was set at $150 \mathrm{~m}$ in this study. The population living behind the protection forest system of more than $150 \mathrm{~m}$ widths will be ensured not to be affected by erosion during storms. In addition, the national coastal protection system along the sea was often not integrated with natural land cover, although they were designed specifically to withstand the impacts of coastal disasters [49].

In addition to the three groups of natural landscapes, the authors separated two groups of human-made landscapes, including artificial coasts with/without beaches. This coastal group was formed for the purpose of coastal economic development in specific areas, such as Quang Ninh, Da Nang, and Binh Dinh provinces [50]. Artificial beaches are often used in tourism and new urban development, while artificial coasts without beaches are often used for ports and other typical economic types. These coasts' location is commonly chosen in high stable coastlines, helping to reduce vulnerability level caused by waves and storm surge.

\subsection{Coastal Vulnerability Assessment Criterion}

\subsubsection{Assessment Index System}

Storms are states of energetic and aggressive nature. Storms affect coastal sediment balances (erosion/accretion) due to strong winds, elevated ocean height, and wave direction along the coast [65]. They create powerful winds clinging to trees and houses, heavy rainfall in suburbs, eroding beaches and coastal resources, and rapid ocean-level waves flooding vast lowland areas. Commonly, the storms affect a large region, therefore the values of the coastal forcing variable can be homogeneous in a long coastline. The coastal vulnerability assessments can be broken down into national, regional, and local scales based on administrative districts [30,38,66,67]. Depending on the purposes of the CVI assessment, researchers can select alternative quantitative variables for different management scales. At the national scale, the coastal forcing related to the storms can be different from the northern to southern parts, but it can be recorded similarly at the regional research scale. Therefore, the input variable selection is the most important in the CVI calculation, avoiding the repetition in using input variables. In this study, the authors 
used the Principal Criteria Analysis (PCA) to assess how important the input variable is and to eliminate the less important variables.

The assessment indicators for each CVI were assigned in terms of considering the impact of the natural and human factors on coastal people's livelihoods. They were divided into two groups of CVI, including natural and socio-economic aspects:

- The natural aspect includes coastal characteristics and forcing. Coastal characteristics' indicators include coastal geology-geomorphology, coastal elevation, coastal slope, shoreline change rate, and coastal natural habitat [32]. The index of coastal characteristics is related to the resilience and erosion vulnerability of the coast. The coastal forcing index includes the rate of sea-level change, mean tidal amplitude, wave heights, and storms. In other words, the coastal forcing index describes the factors that cause erosion due to tides, waves, and storms.

- The socio-economic aspect was divided into two parts, including coastal infrastructure and natural hazards mitigation based on the potential damage or the resilience of coastal features in the face of erosion [10]. Coastal infrastructure indicators include the value of roads, the value of buildings, and the activities of the population. Disaster reduction index can be included in financial revenue, coastal dykes, and embankments. While the coastal infrastructure index is an indicator for assessing potential risks, the disaster mitigation index evaluates the prevention level to mitigate natural hazards, especially coastal erosion.

Climate change increases the frequency and intensity of extreme events and sea level rise causing inundation of wetlands and estuaries [68,69]. Frequent inundation of coastal areas results in coastal erosion, degradation of coastal ecosystems, and reduced effectiveness of existing coastal protection works. When they come ashore, the storm pattern changes, leading to the change in the coastline's shape, which tends to adjust to new conditions $[70,71]$. Effectively making decisions to protect and develop areas at particular erosion risk requires an integrated assessment of current and future catastrophic risks due to climate change or human impacts [72,73]. Therefore, the CVI assessment is a potential tool to predict effects of erosion on coastal people, based on assessing both the factors that increase the vulnerability to the coast and factors that reduce the damage in the face of a disaster.

\subsubsection{Criteria Selection}

The criteria used for calculating the hierarchical CVI index at national and regional scales have been proposed by many scientists $[35,74,75]$, and were also adopted in this study. In the criteria related to the coast's characteristics in Vietnam, criteria related to materials, beach slope, width, and hydrology were taken into account. These criteria were generalized in the criteria of (1) geological structure/structural material composition of the shore, (2) geomorphology/coastal type, and (3) coastal protection level from annual prevailing waves at the national scale, whereas the focusing study at the Central Vietnam required detailed calculations of the beach slope and width, instead of using the variable "geomorphology". In essence, the geological and geomorphologic features clearly separated steep cliffs (composed of acid magma, sandstone, and conglomerate with a slope of 9 and $12 \%$ ) or coasts with bar/coastal dunes (composed of course to fine-grained sediment with a slope below 6\%) [76,77]. Meanwhile, areas that possess a high level of protection against wave energy are accumulation coasts [47]. The slope direction of these areas is opposite with the wind direction, creating beaches over 50-75 $\mathrm{m}$ wide. The data used in the CVI calculation at a national scale included geological, geomorphological, and wavefield maps at the scale of 1:50,000, whereas the data used in the CVI calculation at the Central Vietnam included topographic, remote sensing (ALOS, NOAA, and Google Earth), current situation, and field survey data in 2019 and 2020.

Seven criteria related to coastal forcing were used in the calculation of CVI for both research scales. They measured the hydrographical characteristics with a high level of generalization based on National Hydro-Meteorology Centers along the Vietnam coasts [77,78]. 
Before selecting input coastal forcing variables, the correlation and PCA were conducted to eliminate variables that have strong correlation with each other. The more detailed data will be chosen. According to the climate change scenarios in Vietnam (2016), the differences in both spatial and temporal dimensions of the "significant wave height" have strong correlation with those of the "average wave energy per month" that has been analyzed as the seventh variable (Table 2). Therefore, the significant wave height was replaced by the "average wave energy". The PCA is an important step and has not been done by previous studies, avoiding the repetition in using input variables. The differentiation in wave energy, tidal, sea-level changes, and precipitation could only be observed clearly at the regional scales. This information helped to accurately classify the influence of coastal dynamics on the coasts of the provinces. For example, in the entire coastal strip of Da Nang, the average wave energy is $7 \mathrm{~kW} / \mathrm{m}$, the high-tide amplitude reaches $90 \mathrm{~cm}$, and the total number of storms from 1960 to 2014 was 66, with a frequency of 1.5 storms/year [61]. The average annual rainfall of the coastal strip of Da Nang is $200 \mathrm{~mm}$, while the heaviest rainy day has a flow of $593 \mathrm{~mm}$, corresponding to a high coastal vulnerability province. As another example, wave energy and wave power in Hue, Da Nang, and Quang Nam tend to be two levels lower than in Quang Ngai and Binh Dinh, or the frequency of storms tends to decrease from 4 storms/year in Hue to 3 storms/year in Binh Dinh, and in Nhon Ly, Nhon Hai, and Ghenh Ranh communes, the number of storms is only 2 storms/year. For the criterion "shoreline variation rate (erosion/deposition)", data was calculated in detail based on high-resolution remote sensing data collected from Google Earth from 1965 to 2019, using the Digital Shoreline Analysis System (DSAS) tool. The data generation was explained in detail in previous research of the authors' group [19]. All input data for the CVI calculation was shown in Table 2 and Appendix A.

Table 2. Selected criteria to assess the coastal vulnerability index (CVI) due to erosion in storms at national and regional scales.

\begin{tabular}{|c|c|c|c|c|c|}
\hline \multirow{2}{*}{ No. } & \multirow{2}{*}{ Criteria } & \multirow{2}{*}{ Abreviation } & \multicolumn{2}{|c|}{ Selected Input for CVI } & \multirow{2}{*}{ Input Data Source } \\
\hline & & & Vietnam & Center Part & \\
\hline A & Coastal characteristics & & & & \\
\hline 1 & Geological structure and materials & Geology & $x$ & $\mathrm{x}$ & \multirow{4}{*}{$\begin{array}{c}\text { Geology map with scale of 1:50,000 } \\
\text { Topographical maps, ALOS and } \\
\text { NOAA data } \\
\text { Google earth data, land use/cover maps } \\
\text { and field work }\end{array}$} \\
\hline 2 & Highest slope in $1000 \mathrm{~m}$ radius & HSlope & & $\mathrm{x}$ & \\
\hline 3 & Average slope in $1000 \mathrm{~m}$ radius & ASlope & & $\mathrm{x}$ & \\
\hline 4 & Width of sandy beaches & WBeach & & $x$ & \\
\hline 5 & Geomorphological characteristics & Geomop & $x$ & & $\begin{array}{l}\text { Geomorphological map with scale of } \\
1: 50,000\end{array}$ \\
\hline 6 & $\begin{array}{l}\text { Coastal protection level from annual } \\
\text { prevailing-waves }\end{array}$ & ProAPW & $\mathrm{x}$ & $x$ & Wave and wind data \\
\hline $\mathrm{B}$ & Coastal forcing factors & & & & \\
\hline 7 & Average wave energy & AWat & $x$ & $x$ & \multirow{7}{*}{ Climate change scenarios, 2016} \\
\hline 8 & Highest tidal range & HTidal & $x$ & $x$ & \\
\hline 9 & Average change in sea level (1960s-2014) & ASLC & $x$ & $x$ & \\
\hline 10 & Total water level during storm & TWL & $x$ & $x$ & \\
\hline 11 & Storm frequency & Storm & $x$ & $x$ & \\
\hline 12 & \multirow{2}{*}{$\begin{array}{l}\text { Maximum rainfall (during the day) } \\
\text { Rate of shoreline variation } \\
\text { (erosion/accretion) }\end{array}$} & MRain & $x$ & $x$ & \\
\hline 13 & & Erosion & $x$ & $\mathrm{x}$ & \\
\hline $\mathrm{C}$ & \multicolumn{4}{|l|}{ Socio-economic factors } & \\
\hline 14 & Population density & PopDense & $x$ & $\mathrm{x}$ & $\begin{array}{c}\text { Statistical data in } 2019 \text { (district data at } \\
\text { national level; community data at } \\
\text { regional level) }\end{array}$ \\
\hline 15 & Distance from coastline to buildings & DBuilding & & $\mathrm{x}$ & \multirow{3}{*}{$\begin{array}{c}\text { Google earth data, land use/cover maps } \\
\text { and field work }\end{array}$} \\
\hline 16 & Post-beach surface cover & Landcover & $\mathrm{x}$ & $\mathrm{x}$ & \\
\hline 17 & $\begin{array}{l}\text { Coastal defense constructions } \\
\text { (dykes/embankments/sea walls) }\end{array}$ & Protection & $x$ & $x$ & \\
\hline
\end{tabular}


In addition to the "distance from the coast to residential buildings" criterion, the remaining three socio-economic criteria were used in the CVI assessment at both national and regional scales. The criteria of "population density" and "distance from the coast to residential buildings" represent vulnerable objects which are prone to groups of the coastal forcing factors. Meanwhile, the criteria for "post-beach surface cover" and "coastal defense constructions" represent resilient objects that prevent erosion from impacting people in the land. Thus, the higher the density of the coastal population, the closer to the sea without being protected by a natural protection forest system or artificial structures, the higher the vulnerability [10].

Particularly for the Central Vietnam, the criteria selection was associated with the coastal landscape classification according to the distribution of land covers/uses from the coast to the mainland, as mentioned in Section 2.2.2. Accordingly, each type of coastal landscape has homogeneity of natural (from No.1 to No.6) and socio-economic (from No.14 to No.17) criteria. In this way, the distribution of the land cover/use features from the coast to the mainland was quantified into specific value, instead of qualitative/descriptive ones as in previous studies in Vietnam [50]. In addition to the tourism, economic, and social development goals, the large beach width helps reduce the waves' dynamics to the shore, representing the coastal areas with sedimentary deposits. Additionally, a sparse covering system with plants such as casuarinas, sea spinach, wild pineapple, and other coastal plants grow on the surfaces of embryo- and fore-sandy dunes. These plants develop a strong root system that adheres to the dune surface, helping them stay stable under the impact of light waves and storms $[79,80]$. Therefore, the generation of sandy dunes along the coast has been applied in many countries worldwide to reduce the influence of erosion [81-83]. The survey field showed that many embryo- and fore-dunes on the coast in the Central Vietnam have been destroyed, replaced by artificial constructions or resorts. Therefore, the inclusion of criteria No.2, No.3, No.4, No.15, and No.16 in the CVI vulnerability assessment at the regional scale might help determine the effectiveness of the planning and use of coastal land in the Central Vietnam.

\subsection{Assessment Model Development}

Some methods have been used for weighting coastal vulnerability index systems, mainly such as the process of analytical hierarchy (AHP), entropy weight, and methods of equal weight $[10,35]$. Each methodology has its benefits. This research uses an equal weight approach based on former studies. Although there are no weight assignment guidelines, the arithmetic mean was selected after many experiments depending on statistical mean (e.g., geometric mean, root mean square) and after evaluating the various methods used in the estimation of indices. This approach can therefore take into account all criteria of equal importance, reduces subjectivity, and allows correlation analysis between criteria. This quantitative method reveals the main processes in the evolution of the beach. Some variables became more detailed as the research scale of the study increased, while others became obsolete as they remained constant at the regional/local scale and therefore were not differentiated between areas. Within the GIS method, the numerical values for the CVI variables were summed up, and the results were then standardized by measuring the results as a proportion of the maximum and minimum possible scores. For instance, the calculation of the coastal characteristics (CC) factor is shown below:

$$
\begin{gathered}
\text { Addition of CC indexes }=\sum\left(V_{C C}\right)=\text { Coastal geology }+ \\
\text { Coastal geomorphology }+ \text { Coastal natural protection ability }
\end{gathered}
$$

The outcomes of the index additions varied from 5 to 25, with a highest potential score of 25 and a minimum of 5 . As shown below, the results of this equation were then determined as a percentage of the possible set of scores:

$$
\left.C V I_{i}=100 *\left[\sum\left(V_{i}\right)-n_{i}\right] /\left(5 * n_{i}-n_{i}\right)\right]
$$


" $V_{i}$ " and " $n_{i}$ " respectively, are the corresponding variable data and the number of variables in the CVI group " $i$ ". The average values, consistent with the index grouping, are classified into three groups including natural (N), socio-economic (SE), and vulnerability $(V)$ groups, and calculated for different scales. The average values, consistent with the index grouping, are classified into five groups. For the national scale, the CVI index is calculated as follows:

$$
\begin{aligned}
& \left.C V I_{N 1}=100 *\left[\sum\left(V_{N 1}\right)-10\right] / 40\right] \\
& \left.\left.C V I_{S E 1}=100 *\left[\sum\left(V_{S E 1}\right)-3\right] / 12\right)\right] \\
& \left.C V I_{V 1}=100 *\left[\sum\left(V_{V 1}\right)-13\right] / 52\right]
\end{aligned}
$$

For the regional scale, the CVI index is calculated as follows:

$$
\begin{aligned}
& \left.C V I_{N 2}=100 *\left[\sum\left(V_{N 2}\right)-12\right] / 48\right] \\
& \left.C V I_{S E 2}=100 *\left[\sum\left(V_{S E 2}\right)-4\right] / 16\right] \\
& \left.C V I_{V 2}=100 *\left[\sum\left(V_{V 2}\right)-16\right] / 64\right]
\end{aligned}
$$

\section{Results}

\subsection{Statistical Analysis of Interdependencies}

The PCA was used to analyze to the importance of input parameters in the CVI index. It was based on the correlation analysis between all input parameters shown in Table 2. The importance of each parameter is shown in both sub-figures in Figure 4. Based on the PCA analysis shown in Figure 4, the variables related to geology, slope, erosion, distance from coast to residential building, and width of coastal protection forest are all clearly shown at dimension 1. Meanwhile, coastal forcing factors, including wave, tidal, and storm characteristics, are clearly reflected in dimension 2 . The dimensions 1 and 2 interpret $26 \%$ and $16 \%$ respectively, of the variation between the analyzed variables. Accordingly, the variables of slope, distance from coast to residential building, and protection forest width have strong positive correlations. These variables have negative correlations with "Protection" and "PopDense" variables in both dimensions. Similarly, the variables "Mtidal" and "AWat" have negative correlations with the variables "Storm", "Geology", "WBeach", and "Erosion".

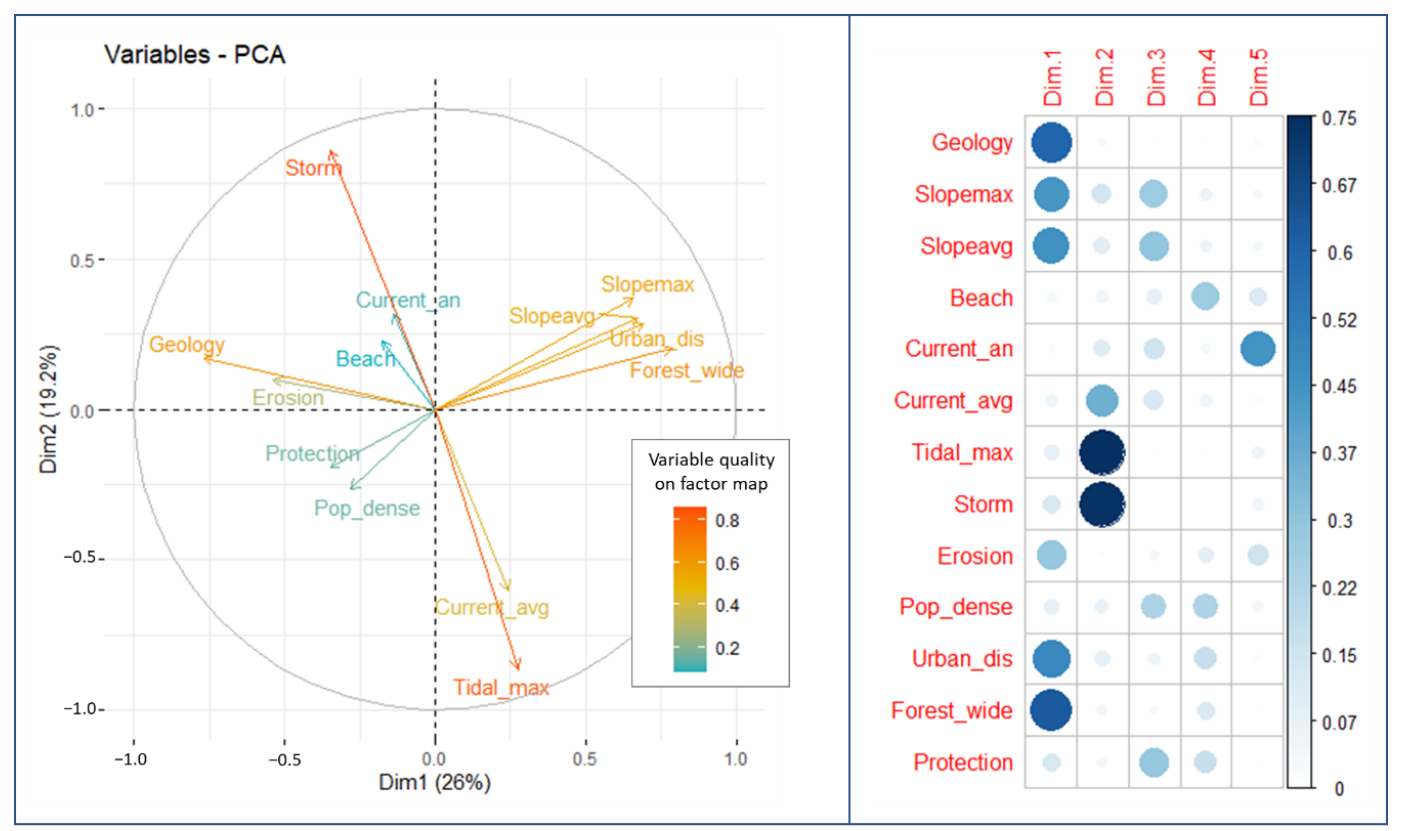

Figure 4. Principle Component Analysis of CVI variables (left) and the contribution of variables in five dimensions (right). 


\subsection{Multi-Scale CVI Assessments}

\subsubsection{Due to Erosion in Vietnam}

Based on 13 CVI assessment criteria, more than $20 \%$ of the Vietnam coastline has a high to very high vulnerability (Figure 5). In general, the Central region has the highest levels of vulnerability caused by coastal erosion. The calculation results show that nearly $40 \%(250 \mathrm{~km})$ of the North Central Coast have CVI scores above level 4, particularly in the Mui Ron-Mui Rong cell (Figure 6). Meanwhile, another 20\% (equivalent to $280 \mathrm{~km}$ ) in the South-Central part had a CVI of above 4, for example, in Son Tra-Cua Dai, Lo Dieu-Phuoc Mai, Phuoc Mai Peninsula-Ghenh Rang (ThP. Quy Nhon), Ghenh Rang-Phung Xuan Dai, and Hon Chua-Cape Dai Lanh (Mui Ne) cells. In detail, at the CVI index level 5, these coasts are areas with high population density over 400 people $/ \mathrm{km}^{2}$, average wave energy is over $6.5 \mathrm{~kW} / \mathrm{m}$, with storm frequency of about one event/year. Meanwhile, the highest tidal range in these areas is only level 2, corresponding to a $90-130 \mathrm{~cm}$ low level compared to other coastal cells in Vietnam.

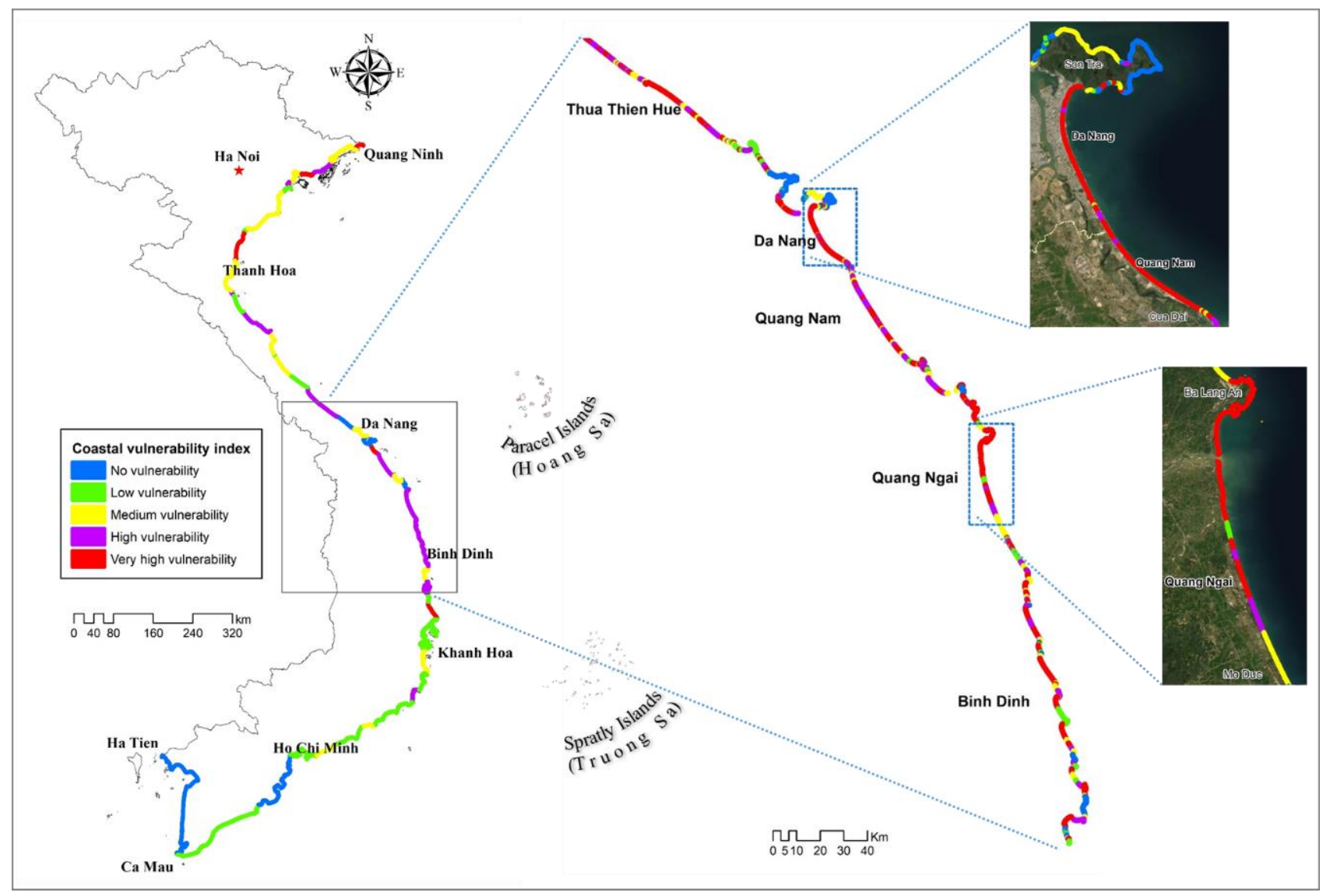

Figure 5. Coastal vulnerability assessments at national and regional scales in Vietnam.

More than $1700 \mathrm{~km}$ of Vietnam's coastline has the "low" and "no" level of vulnerability, mainly concentrated in bays and sheltered areas, especially the cell from Ca Mau to Ha Tien. More than $55 \%$ of the coastal cells of South-Central Vietnam have a CVI of low to no level, particularly in the Ca Na to Vung Tau cell. Likewise, in the Northern and Southern coastal cells, despite the long coastline, the CVI is still assessed at a low level. The South Coast region alone is assessed to be very stable, with a CVI index of less than 1 . Although the coasts in the Gulf of Tonkin and the north of the North Central region are heavily affected by rain and storms with a highly dense population, the coastal vulnerability in this area is assessed at a low level due to coastal protection works. 


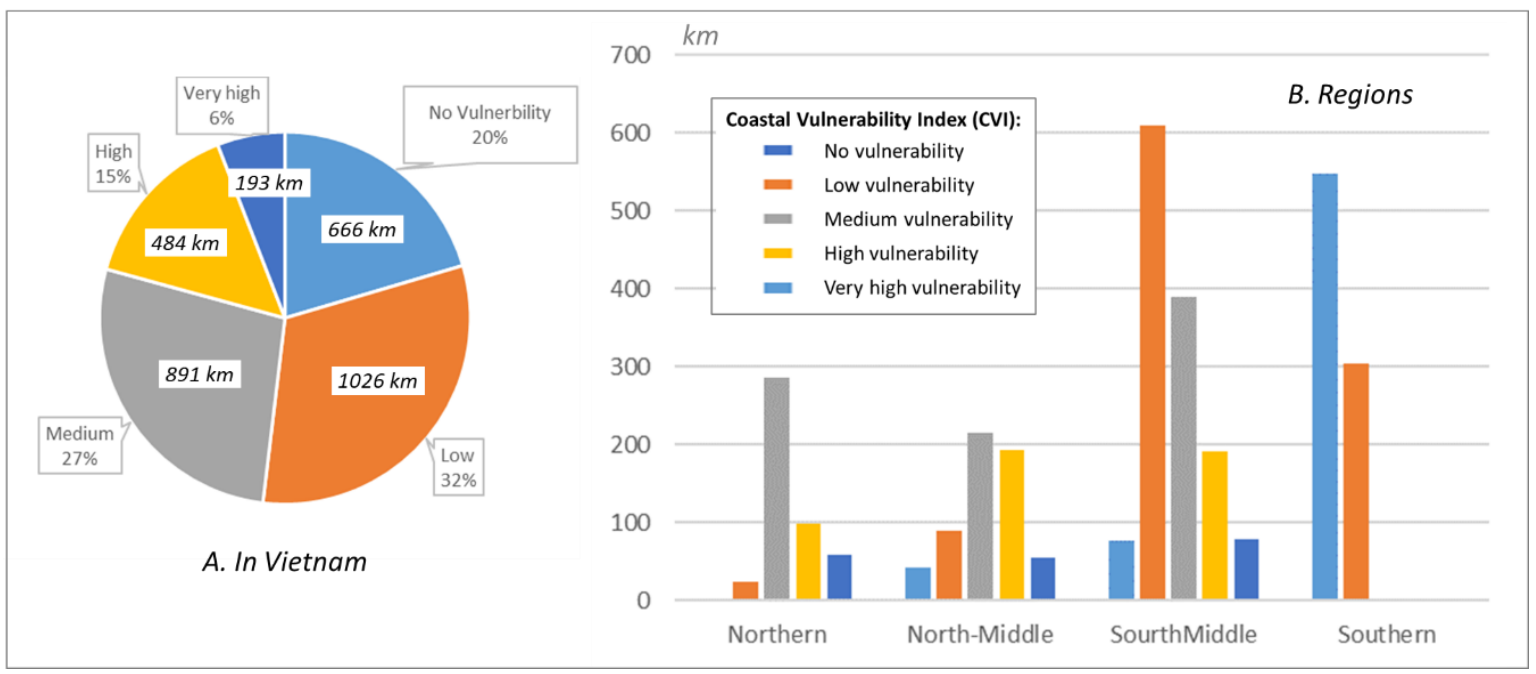

Figure 6. Coastal vulnerability assessments due to erosion in Vietnam (left) and in four regions (right).

\subsubsection{Due to Erosion in the Central Vietnam}

Based on 16 CVI evaluation criteria, more than $60 \%$ of the Central Coast is rated as "high" to "very high" (Figures 5 and 7). The coastal cells with low CVI (below the value of 1) account for about $24 \%$, concentrated in provinces such as Thua Thien Hue, Da Nang, and Binh Dinh. However, more than $80 \mathrm{~km}$ of the shoreline in these provinces still had CVI levels above 4, such as in the southern cells of Thuan An estuary (in Phu Thuan commune, Thua Thien Hue) and the southern cells of Tam Quan Nam (in Hoai Hai commune, Binh Dinh). The coastal strip of Da Nang has an average natural vulnerability, but with a stable embankment quality in Da Nang province, the overall CVI vulnerability here decreased significantly.

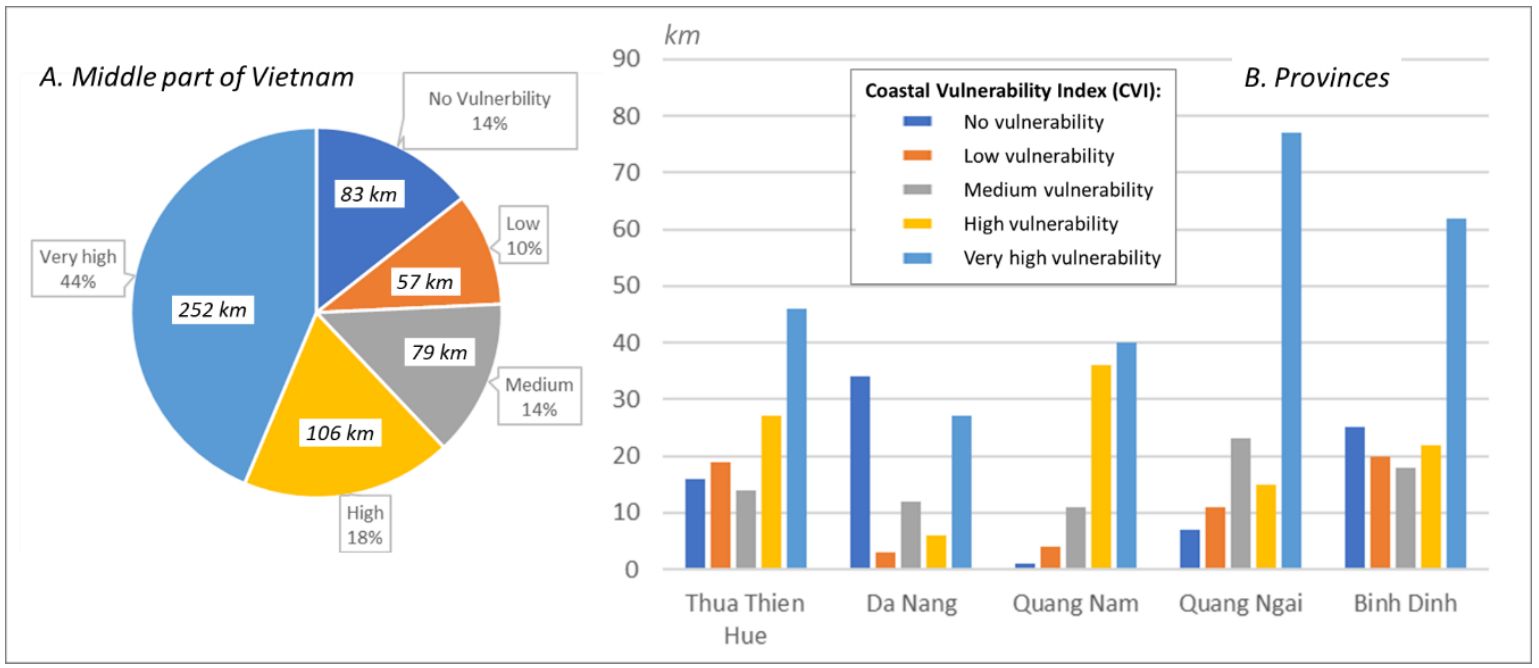

Figure 7. Coastal vulnerability assessments due to erosion in the Central Vietnam (left) and in five focusing provinces (right).

The CVI calculated for Quang Nam and Quang Ngai areas reached a high threshold, with more than 40 and $80 \mathrm{~km}$ of very high-vulnerability coasts, respectively (approximately $40-60 \%$ of the shoreline) - only about $4 \%$ of the coast is not affected by erosion. The very high CVI shorelines are assessed in Hoi An and Cua Dai, Quang Nam province. Meanwhile, the area with very high CVI in Quang Ngai province is mainly concentrated in Tinh Ky and Tinh Khe communes, Quang Ngai city. At $252 \mathrm{~km}$ of coastline with CVI of level 5, they are all peaceful beaches with slopes less than $3 \%$, beach widths less than $50 \mathrm{~m}$, the population 
of over 600 people $/ \mathrm{km}^{2}$ close to the coast, with protection forest width less than $25 \mathrm{~m}$. It makes these cells of the coast considered at high risk of erosion, although the average annual wave energy and the frequency of storms are moderate (1.3 to 1.7 storms/year).

\subsection{Index in Landscape Types}

The statistical results of the coastal vulnerability index for each type of coast in the Central region are shown in Figures 8 and 9. The research results for both research scales are nearly similar. In general, the estuarine landscapes witnessed the highest vulnerability index, followed by sandy and artificial landscapes. In particular, the CVI of estuary landscapes, on average, was only equal to the sandy landscapes (below threshold 3.5), and at the Cua Dai area existed some coasts with the highest CVI index (threshold 5). The cliff landscapes have low CVI values, whereas about $10 \%$ of these landscapes in the Southern part of the Center region have the CVI at a medium level.

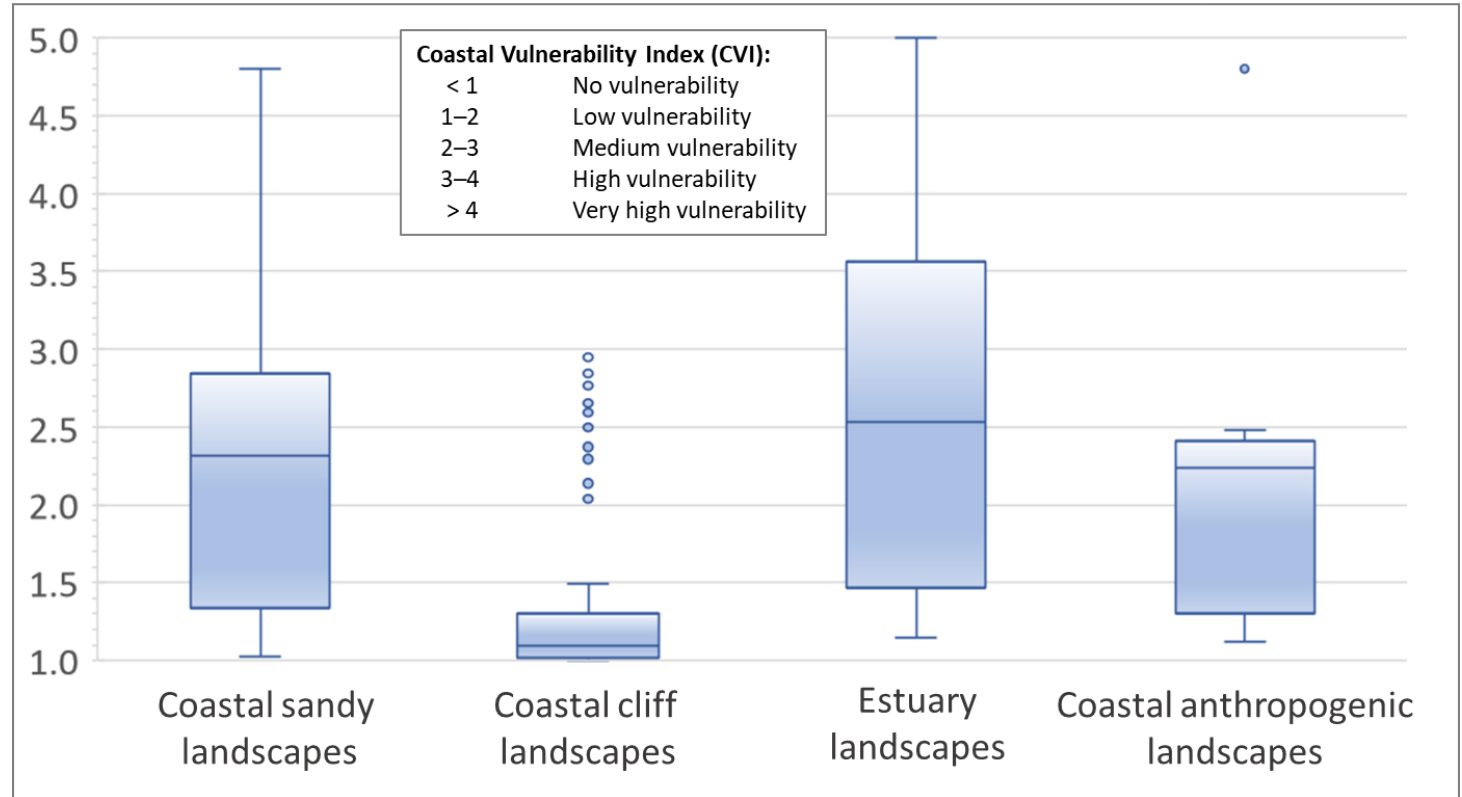

Figure 8. CVI index in four main coastal landscape groups in Central Vietnam.

In the group of sandy and estuary landscapes shown in Figure 9, ten coastlines belonging to these two groups experienced vulnerability at level 4 or higher. According to the median CVI values, only three coastal landscapes have the CVI value higher than 2.5, including: (1.4) coasts of construction and tourism landscapes close to the sea, (3.2) stable estuarial sand-bar landscapes used for rural and agricultural development, and (3.3) stable estuarial sand-bar landscapes used for tourism and other constructions. Additionally, about $20 \%$ of other coasts in the coastal sandy and estuary groups with the value higher than 2.5 can be affected by storms. Besides the residents of people close to the sea, the aquacultural and other agricultural landscapes have been strongly affected by storms, leading to property damage partly in these coastal landscapes. Importantly, Figure 9 shows the real effects of the erosion in storms generated by the interaction between nature and socio-economic factors. The coastal landscapes No.1.4, No.3.2, and No.3.3 must be protected, and $20 \%$ of the area in the landscapes No.1.1, No.1.2, No.1.3, and No. 3.1 should be improved.

The cliff landscapes with stable geomorphology and geological structure and sparsely populated were the places with the lowest vulnerability level. The points with the highest CVI level on the cliff landscapes were at the rural populations with moderate agricultural activities. Most of the sandy landscapes between cliffs have no coastal vulnerability, except some sandy landscapes have been used for tourism development in Binh Dinh and Quang Nam provinces. 


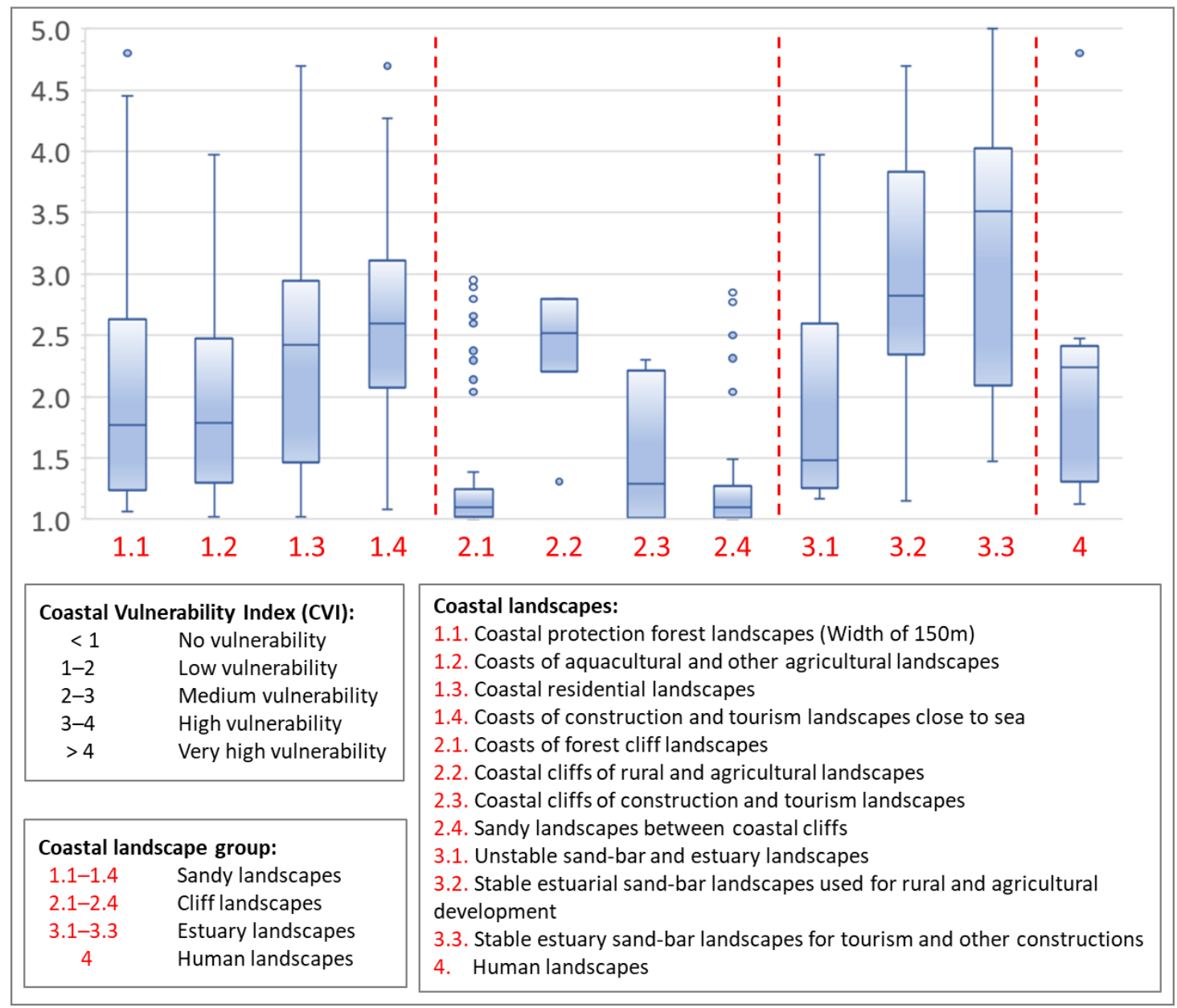

Figure 9. CVI index in 12 sub-coastal landscapes in Central Vietnam.

\section{Discussion}

\subsection{Comparison with Formal CVI Assessments}

The study has shown the feasibility of using criteria to calculate CVI at different research scales. The use of the CVI criteria in this study was inherited from those in the previous studies $[10,30,35,38]$. The climatic and hydrological conditions are relevant to a CVI assessment at both national and regional scales. They also can be used similarly at local scales. Additionally, the study used some additional criteria for representing geomorphological characteristics and land management. When studying in detail, these criteria are still included in the calculation, but they will be calculated as a fixed constant for a long coastline. At the regional and local scales, topographical information, and physical and socio-economic composition have clarified both natural and artificial impacts on coastal protection [10]. Instead of using the geomorphologic features on the national scale, slope, beach width, and exact width of coastal forest cover are employed when calculating the CVI on the regional and local scale. The use of these two detailed criteria at a national scale will result in data overload and data generality loss.

In new artificial urban construction or tourist landscapes, the natural vulnerability level varies significantly. The criteria No.15 and No.16 are included to evaluate the correlation between populated coasts or tourist structures close to the sea with the degree of coastal erosion. Commonly, the artificial coasts in Vietnam have been chosen in the coastal landscape types $1.3,1.4,3.2$, and 3.3. Regarding vulnerability level by coastal characteristics (CC), the artificial coasts will experience a higher CVI than the natural coasts. Due to the new construction of the human-made coasts, the sediment equilibrium is changed (from the gentle surface to the vertical shoreline surface), affecting the wave breaking zone 
and the longshore current and increasing erosion at artificial coasts [19]. The artificial coasts' foot will be continuously eroded, possibly leading to a complete collapse at dyke foot. The artificial construction destroyed the natural coastal environment [10], leading to increased coastal vulnerability due to erosion up to high and very high levels. Therefore, it is necessary to choose a suitable location for developing the artificial coasts, such as in areas with opposite aspect to coming wind/wave, slope higher than $6 \%$, coastal forcing factors lower than level 3 (shown in Appendix A), more than $200 \mathrm{~m}$ from the coastline, and having a more than $100 \mathrm{~m}$ protection forest in front of beaches. It accounts for more than $25 \%$ of the total coastal cells according to patterns 1.3 and $1.4,40 \%$ of the total number of coastal cells according to type 3.2 , and $70 \%$ of the total number of coastal cells according to type 3.3 (Figures 5, 6 and 9). Coastal anti-erosion works on artificial coasts have been used as potential practices to raise defenses and elevate the coastline height. Accordingly, new coastal urban residential areas in artificial coasts can minimize the effects of extreme events.

\subsection{Vulnerability Assessment in Central Vietnam}

The CVI assessment was clearly validated at the national scale. According to the National Disaster Inventories (https:/ / www.desinventar.net/DesInventar/profiletab.jsp\# more_info), the CVI results are in harmony with the number of deaths and destroyed/ damaged houses due to the effects of storms in coastal provinces, as shown in Figure 5. Particularly, the highest number of deaths, more than 70 people/year, was found in Quang Ninh, Thanh Hoa, Da Nang, and Binh Dinh. Some coastal provinces have a number of deaths due to the effects of storms from 24 to 70 people, which includes Ha Tinh, Quang Tri, Quang Nam, and Quang Ngai. Additionally, more than 25,000 houses in Central Vietnam are destroyed and damaged annually by storms. The lowest death number (less than one person/year) was also recorded in the provinces in the southern part of Vietnam or in the Red river delta.

In Central Vietnam, the validation process can be done based on the interview and the remote sensing analysis. According to local households, coastal livelihood activities of local people such as fishing, agriculture, or farming at coastal lagoons have all been built backward on the coast. Through three interviews in 2018, 2019, and 2020, in front of these residential and agricultural areas, a forest cover has been commonly planted over $100 \mathrm{~m}$ wide since the 1970s. It proves that the lives of coastal people have adapted to the impacts of waves and storms from many generations. It is similar to both coastal urban and rural landscapes. Most rural land is located more than $100 \mathrm{~m}$ from the coast, protected by rows of casuarina trees and stable foredunes [19]. The local people also affirmed that the waves and sea level only reach the outer edge of the casuarina tree line, rarely affecting the houses inside, except for the extreme storms.

Recently, many coastal constructions have been planned and rebuilt for economic and tourism development purposes, such as Lang Co tourist area (Thua Thien Hue), Ngu Hanh Son (Da Nang), Hoi An (Quang Nam), or Tam Quan (Binh Dinh) [84,85]. The clump-root vegetation is deeply rooted in the coastal sand layer, helping to stabilize the front-end sand dunes. When the coast loses this natural protective forest system, the broken wave zone will penetrate further inland. It is a favorable condition for waves and storms to go inland, causing land loss and affecting people's livelihoods inside. Especially during the stormy season, the sea level rises, combined with the waves, will destroy deeply into the foredunes without forest landcover.

The Son Tra-Cua Dai region is a typical example of coastal land reclamation, serving economic and tourism development. With a stable rocky coast and low population density, the Son Tra peninsula's cliff landscape has a low vulnerability level. Although the coastal protection with coastal roads and embankments were built in the sandy landscapes, nearly $20 \%$ of urban development and tourism development here are very vulnerable to erosion during storms. The northern area from Tho Quang ward, Da Nang province to Ngu Hanh Son district, Quang Nam province, is often affected by storms and waves that flood coastal roads. However, the coastal road system is built higher than beaches from 3 to 
$5 \mathrm{~m}$, and significantly limits the impact of coastal erosion. However, the southern coasts of the Son Tra-Cua Dai region are frequently eroded, especially in Hoi An, Quang Nam province. According to Reference [19], many cells of the northern part of Quang Nam province have been eroded over $10 \mathrm{~m}$ /year due to the conversion from natural forests to tourism and urban constructions. According to the results, 16 coastal cells with high to very high CVI index (levels 4 and 5, respectively) are at highly dense population (over 600 people $/ \mathrm{km}^{2}$ ), close to the sea, or have been planned/built tourist resorts. Completed tourist sites commonly have relatively high greenery coverage along the coast. However, the field survey showed that the colonial system in the coastal tourism landscapes serves sightseeing tourism and relaxation, instead of the protective function of casuarina trees. Several of the tourism cells in Quang Nam province have installed revetments/sea walls, but only for the internal area of each resort [19]. For instance, many resorts such as Victoria Hoi An Beach Resort, Golden Sand Resort and Spa Hoi An, Sunrise Premium Resort Hoi An, and Vinpearl Resort and Spa Hoi An all have to build their coastal embankment system to minimize wave damage and sea-level rise during annual typhoons.

The estuary landscapes have a complicated level of coastline change (erosion and deposition), leading the high CVI values. The population density in these areas is medium, together with underdeveloped economy in the unstable estuarine sand dunes. Especially, the residential areas, agricultural activities, tourist areas, and other construction works in the estuarine landscapes have a higher degree of CVI. Like the sandy landscapes, the indigenous people in the sand-bar landscapes have adapted and lived for a long time. Residential areas are often 100-150 m inland, minimizing the impacts of waves and sea level rise in storms. However, as a river-sea transition region, the coastal erosion is potentially estimated above $5-8 \mathrm{~m}$ /year in these landscapes, resulting in a high CVI index level. The areas under construction and tourism development have the highest CVI values due to the destruction of the front protection forest width, replaced by tourist green landscapes.

\section{Conclusions}

Through the results and assessment of coastal vulnerability level due to erosion and storm surge above, the questions raised in Section 1 can be answered as follows:

1. Is it feasible to use coastal landscape classification systems for CVI assessments at national and regional scales? Yes, it is. At the national scale, the coastal classification based on four geomorphic features makes the CVI criteria useful in the case of data scarcity. While, at the regional scale, in addition to the geomorphological information, the coastal landscape classification to assess coastal vulnerability requires detailed information about the distance from the coast (a) to human works and (b) the width of coastal protection forest behind the beach. Two of these criteria have been used effectively to calculate CVI to clarify the direct impact of waves and storm surge on the coastal population.

2. How is the selection of CVI assessment criteria at national and regional scales different? The calculation of CVI at the national scale only uses 13 generalized coastal characteristics, coastal forcing, and socio-economic criteria to determine the differentiation between 72 natural regions, while the calculation at the regional scale requires 16 coastal criteria with a higher level of detail, which helps determine the regional differentiation between 41 specific landscape types. For CVI calculations at the regional scales, the CVI index needs to add three additional criteria: (i) slope, (ii) the distance from the coast to the residential works, and (iii) the width of protection forest in front of the sea.

3. How vulnerable are the coasts in Vietnam and Central Vietnam to erosion in storms? The coastal vulnerability value caused by erosion is highest in the South-Central region, followed by the North Central Coast, while the Northern and Southern regions of Vietnam are assessed at low to medium levels. The Son Tra-Cua Dai region witnessed a high CVI level, especially the coastal cells with residential activities and tourism development close to the sea.

Instead of using the traditional CVI formulas and long-term data, decision-making models based on artificial intelligence algorithms can be developed. Real statistics related to 
the number of deaths or poverty loss can be used as an indicator of the coastal vulnerability. The real and short-term statistical data in detail can be collected at district/local scales. The PCA can be improved to identify the correlation between input variables with real data. Afterwards, there is high potential to apply high-technic models such as artificial intelligent models in the CVI assessments. Accordingly, the CVI index can be updated quickly once the models are trained. It can be set up in the future.

Author Contributions: Conceptualization, C.H.N., K.B.D. and V.B.D.; methodology, K.B.D., Q.H.T., T.L.G. and V.L.N.; software, T.T.H. and D.H.N.; validation, Q.H.T., T.N.D. and T.P.N.P.; formal analysis, T.L.G., T.T.H. and K.B.D.; investigation, C.H.N. and V.B.D.; resources, V.B.D., C.C.N. and V.L.N.; data curation, K.B.D. and C.H.N.; writing-original draft preparation, K.B.D. and C.H.N.; writing-review and editing, K.B.D., C.H.N., T.P.N.P. and T.T.H.; visualization, T.P.N.P. and T.L.G.; supervision, K.B.D. and V.L.N.; project administration, C.H.N.; funding acquisition, C.H.N. All authors have read and agreed to the published version of the manuscript.

Funding: This research is funded by Vietnam National Foundation for Science and Technology Development (NAFOSTED) under Grant Number [105.07-2013.19].

Institutional Review Board Statement: Not applicable.

Informed Consent Statement: Not applicable.

Data Availability Statement: The data presented in this study are available on request from the corresponding author. The data are not publicly available due to privacy.

Acknowledgments: We are grateful to our team for their advice and encouragement. We also want to thank Pham Thi Xuan Quynh for language correction. We are grateful for the time and efforts of the editors and the anonymous reviewers on improving our manuscript.

Conflicts of Interest: The authors declare no conflict of interest.

\section{Appendix A}

Table A1. Coastal vulnerability levels for each criterion to assess the coastal vulnerability due to erosion in storms.

\begin{tabular}{|c|c|c|c|c|c|c|c|}
\hline \multirow{3}{*}{ No. } & \multirow{3}{*}{ Criterion } & \multirow{3}{*}{ Unit } & \multicolumn{5}{|c|}{ Coastal Vulnerability Level } \\
\hline & & & No & Low & Medium & High & Very High \\
\hline & & & 1 & 2 & 3 & 4 & 5 \\
\hline A & Coastal characteristics & & & & & & \\
\hline 1 & $\begin{array}{l}\text { Geological structure and } \\
\text { materials }\end{array}$ & - & $\begin{array}{l}\text { Magma acids } \\
\text { (e.g., granite and } \\
\text { riolites) }\end{array}$ & $\begin{array}{l}\text { Metamorphic } \\
\text { rocks, magma, } \\
\text { and sandstone }\end{array}$ & $\begin{array}{c}\text { Fine-fine grained } \\
\text { sedimentary } \\
\text { rock }\end{array}$ & $\begin{array}{l}\text { Poor cohesive } \\
\text { coarse grain } \\
\text { sediment }\end{array}$ & $\begin{array}{l}\text { Homogeneous, } \\
\text { fine-grained } \\
\text { sediment }\end{array}$ \\
\hline 2 & $\begin{array}{l}\text { Highest slope in } 1000 \mathrm{~m} \\
\text { radius }\end{array}$ & - & $>12$ & $9-12$ & 6-9 & $3-6$ & $<3$ \\
\hline 3 & $\begin{array}{c}\text { Average slope in } 1000 \mathrm{~m} \\
\text { radius }\end{array}$ & $\%$ & $>12$ & $9-12$ & $6-9$ & $3-6$ & $<3$ \\
\hline 4 & Width of sandy beaches & $\mathrm{m}$ & $>300$ & $150-300$ & $75-150$ & $25-75$ & $<25$ \\
\hline 5 & $\begin{array}{l}\text { Geomorphological } \\
\text { characteristics }\end{array}$ & - & $\begin{array}{l}\text { Coastal steep } \\
\text { cliffs }\end{array}$ & $\begin{array}{l}\text { Coastal gentle } \\
\text { cliffs }\end{array}$ & $\begin{array}{l}\text { Heterogeneous } \\
\text { coastal cliffs, } \\
\text { stable estuaries }\end{array}$ & $\begin{array}{c}\text { Sandy bars, } \\
\text { pebbles/gravel } \\
\text { shore, lagoon }\end{array}$ & $\begin{array}{c}\text { Eroded estuaries } \\
\text { delta areas }\end{array}$ \\
\hline 6 & $\begin{array}{l}\text { Coastal protection level from } \\
\text { annual prevailing-waves }\end{array}$ & - & $\begin{array}{c}\text { Opposite sides of } \\
\text { coming } \\
\text { wind/wave }\end{array}$ & $\begin{array}{c}\text { Opposite sides of } \\
\text { coming } \\
\text { wind/wave in } \\
\text { unstable cliffs }\end{array}$ & $\begin{array}{l}\text { Partly opposite } \\
\text { sides of coming } \\
\text { wind/wave }\end{array}$ & $\begin{array}{l}\text { Direct exposure } \\
\text { to waves, but } \\
\text { energy is slightly } \\
\text { refracted from } \\
\text { offshore }\end{array}$ & $\begin{array}{l}\text { Direct exposure } \\
\text { to the impact of } \\
\text { storm waves } \\
\text { without defense }\end{array}$ \\
\hline B & Coastal forcing factors & & & & & & \\
\hline 7 & Average wave energy & $\begin{array}{l}\text { TW/ } \\
\text { month }\end{array}$ & $<1.5$ & $1.5-4.2$ & $4.2-6.5$ & $6.5-9$ & $>9$ \\
\hline 8 & Highest tidal range & $\mathrm{cm}$ & $<90$ & $90-130$ & $130-170$ & $170-200$ & $>200$ \\
\hline 9 & $\begin{array}{c}\text { Average change in sea level } \\
\qquad(1960 s-2014)\end{array}$ & $\mathrm{m}$ & $<-4.0$ & $-4.5-0.5$ & $-0.5-3$ & $3-5.5$ & $>5.5$ \\
\hline 10 & $\begin{array}{c}\text { Total water level during } \\
\text { storm }\end{array}$ & $\mathrm{m}$ & $<40$ & $40-60$ & $60-80$ & $80-100$ & $>100$ \\
\hline 11 & Storm frequency & Event/year & $<0.9$ & $0.9-1.3$ & $1.3-1.7$ & $1.7-2.1$ & $>2.1$ \\
\hline 12 & $\begin{array}{l}\text { Maximum rainfall (during } \\
\text { the day) }\end{array}$ & $\mathrm{mm}$ & $<300$ & $300-500$ & $500-700$ & $700-900$ & $>900$ \\
\hline 13 & $\begin{array}{l}\text { Rate of shoreline variation } \\
\text { (erosion/accretion) }\end{array}$ & $\begin{array}{l}\mathrm{m} / \\
\text { year }\end{array}$ & $>0$ (accretion) & -1 to 0 & -3 to -1 & -5 to -3 & $<-5$ \\
\hline
\end{tabular}


Table A1. Cont.

\begin{tabular}{|c|c|c|c|c|c|c|c|}
\hline \multirow{3}{*}{ No. } & \multirow{3}{*}{ Criterion } & \multirow{3}{*}{ Unit } & \multicolumn{5}{|c|}{ Coastal Vulnerability Level } \\
\hline & & & No & Low & Medium & High & Very High \\
\hline & & & 1 & 2 & 3 & 4 & 5 \\
\hline $\mathrm{C}$ & Socio-Economic factors & & & & & & \\
\hline 14 & Population density & Person $/ \mathrm{km}^{2}$ & $<100$ & $100-200$ & $200-400$ & $400-600$ & $>600$ \\
\hline 15 & $\begin{array}{c}\text { Distance from coastline to } \\
\text { buildings }\end{array}$ & $\mathrm{m}$ & $>600$ & $200-600$ & $100-200$ & $50-100$ & $<50$ \\
\hline 16 & $\begin{array}{l}\text { Land cover type behind } \\
\text { beaches }\end{array}$ & - & $\begin{array}{l}\text { Protection forest } \\
\text { (including } \\
\text { mangrove) }\end{array}$ & $\begin{array}{l}\text { Sparse } \\
\text { vegetation and } \\
\text { agriculture }\end{array}$ & $\begin{array}{l}\text { Rural with } \\
\text { vegetation }\end{array}$ & $\begin{array}{l}\text { Urbanized areas } \\
\text { with sparse } \\
\text { vegetation }\end{array}$ & $\begin{array}{l}\text { Urban, } \\
\text { industrials, ports, } \\
\text { and tourism } \\
\text { areas }\end{array}$ \\
\hline 17 & $\begin{array}{c}\text { Coastal protection } \\
\text { constructions } \\
\text { (dykes/embankments/sea } \\
\text { walls) }\end{array}$ & - & $\begin{array}{l}\text { Very solid } \\
\text { sea-walls }\end{array}$ & $\begin{array}{c}\text { Solid } \\
\text { construction }\end{array}$ & $\begin{array}{l}\text { Semi-solid } \\
\text { construction }\end{array}$ & $\begin{array}{c}\text { Temporary } \\
\text { dyke/embankment }\end{array}$ & No construction \\
\hline
\end{tabular}

\section{References}

1. Liquete, C.; Zulian, G.; Delgado, I.; Stips, A.; Maes, J. Assessment of coastal protection as an ecosystem service in Europe. Ecol. Indic. 2013, 30, 205-217. [CrossRef]

2. Theodoro, G.; Pereira, N.; Lima, D.; Cristina, V.; Sanches, L.; Ferreira, R. Identifying driving forces of landscape changes: Historical relationships and the availability of ecosystem services in the Atlantic forest. Ecosyst. Serv. 2016, 22, 11-17. [CrossRef]

3. Van der Biest, K.; De Nocker, L.; Provoost, S.; Boerema, A.; Staes, J.; Meire, P. Dune dynamics safeguard ecosystem services. Ocean Coast. Manag. 2017, 149, 148-158. [CrossRef]

4. Aparna, P.; Nigee, K.; Shimna, P.; Drissia, T.K. Quantitative Analysis of Geomorphology and Flow Pattern Analysis of Muvattupuzha River Basin Using Geographic Information System. Aquat. Procedia 2015, 4, 609-616. [CrossRef]

5. Pye, K.; Blott, S.J. The geomorphology of UK estuaries: The role of geological controls, antecedent conditions and human activities. Estuar. Coast. Shelf Sci. 2014, 150, 196-214. [CrossRef]

6. Boak, E.H.; Turner, I.L. Shoreline Definition and Detection: A Review. J. Coast. Res. 2005, 214, 688-703. [CrossRef]

7. Cooper, J.A.G.; O'Connor, M.C.; McIvor, S. Coastal defences versus coastal ecosystems: A regional appraisal. Mar. Policy 2016, 111, 102332. [CrossRef]

8. Alongi, D.M. Present state and future of the world's mangrove forests. Environ. Conserv. 2002, 29, 331-349. [CrossRef]

9. Hapke, C.; Plant, N. Predicting coastal cliff erosion using a Bayesian probabilistic model. Mar. Geol. 2010, 278, 140-149. [CrossRef]

10. Zhu, Z.T.; Cai, F.; Chen, S.L.; Gu, D.Q.; Feng, A.P.; Cao, C.; Qi, H.S.; Lei, G. Coastal vulnerability to erosion using a multi-criteria index: A case study of the Xiamen coast. Sustainability 2018, 11, 93. [CrossRef]

11. Van Cong, L.; Van Cu, N.; Shibayama, T. Assessment of Vietnam Coastal Erosion and Relevant Laws and Policies; Elsevier: Amsterdam, The Netherlands, 2014; ISBN 9780128004791.

12. Vu, V.P. Studying and Assessing Coastal Changes in Southern Provinces (Vietnam) under the Impact of Climate Change and Sea Level Rise; Vietnam National University Press: Hanoi, Vietnam, 2013. (In Vietnamese)

13. Noy, I.; Vu, T.B. The economics of natural disasters in a developing country: The case of Vietnam. J. Asian Econ. 2010, 21, 345-354. [CrossRef]

14. Takagi, H.; Thao, N.D.; Esteban, M.; Mikami, T.; Van Cong, L.; Ca, V.T. Coastal Disasters in Vietnam; Elsevier: Amsterdam, The Netherlands, 2015; ISBN 9780128012703.

15. Takagi, H.; Esteban, M.; Thao, N.D. Introduction: Coastal Disasters and Climate Change in Vietnam; Elsevier: Amsterdam, The Netherlands, 2014; ISBN 9780128004791.

16. Trinh, T.-A.; Feeny, S.; Posso, A. The Impact of Natural Disasters and Climate Change on Agriculture: Findings from Vietnam. In Economic Effects of Natural Disasters; Academic Press: Cambridge, MA, USA, 2021; pp. 261-280. ISBN 9780128174654.

17. Nguyen, V.N.; Ginige, K.; Greenwood, D. Challenges in integrating disaster risk reduction into the built environment-The Vietnam context. Procedia Eng. 2018, 212, 316-323. [CrossRef]

18. Nguyen, X.H.; Le, B.T. Coastal Geomorphology in Vietnam; Science and Technology Publishing House: Hanoi, Vietnam, 2007.

19. Ngo, V.L.; Dang, V.B.; Dang, K.B.; Ngo, C.C.; Pham, T.P.N.; Benjamin, B.; Giap, T.K.C. Assessment of shoreline changes for setback zone establishment from Son Tra (Da Nang city) to Cua Dai (Hoi An city), Vietnam. Vietnam J. Earth Sci. 2020, 42, 363-383.

20. Fitton, J.M.; Hansom, J.D.; Rennie, A.F. A national coastal erosion susceptibility model for scotland. Ocean Coast. Manag. 2016, 132, 80-89. [CrossRef]

21. Coca-Domínguez, O.; Ricaurte-Villota, C. Validation of the hazard and vulnerability analysis of coastal erosion in the Caribbean and pacific coast of Colombia. J. Mar. Sci. Eng. 2019, 7, 260. [CrossRef]

22. Ahmed, N.; Howlader, N.; Hoque, M.A.A.; Pradhan, B. Coastal erosion vulnerability assessment along the eastern coast of Bangladesh using geospatial techniques. Ocean Coast. Manag. 2021, 199, 105408. [CrossRef]

23. Różyński, G. Parameterization of erosion vulnerability at coasts with multiple bars: A case study of Baltic Sea coastal segment in Poland. Coast. Eng. 2020, 159, 103723. [CrossRef] 
24. Rizzo, A.; Vandelli, V.; Buhagiar, G.; Micallef, A.S.; Soldati, M. Coastal vulnerability assessment along the north-eastern sector of Gozo Island (Malta, Mediterranean Sea). Water 2020, 12, 1405. [CrossRef]

25. Torresan, S.; Gallina, V.; Gualdi, S.; Bellafiore, D.; Umgiesser, G.; Carniel, S.; Sclavo, M.; Benetazzo, A.; Giubilato, E.; Critto, A. Assessment of climate change impacts in the North Adriatic coastal area. Part I: A multi-model chain for the definition of climate change hazard scenarios. Water 2019, 11, 1157. [CrossRef]

26. Gallina, V.; Torresan, S.; Zabeo, A.; Rizzi, J.; Carniel, S.; Sclavo, M.; Pizzol, L.; Marcomini, A.; Critto, A. Assessment of climate change impacts in the North Adriatic coastal area. Part II: Consequences for coastal erosion impacts at the regional scale. Water 2019, 11, 1300. [CrossRef]

27. Cham, D.D.; Nguyen, H.S.; Nguyen, K.A. Coastal Vulnerability Assessments Due to Climate Change in Coastal Sand-bar in Quang Binh, Quang Tri, Thua Thien Hue to Propose Sustainable Likelihood; Science and Technics Publishing House: Hanoi, Vietnam, 2020.

28. Hung, N.T.; Duc, D.M.; Quynh, D.T.; Cuong, V.D. Nearshore topographical changes and coastal stability in Nam Dinh Province, Vietnam. J. Mar. Sci. Eng. 2020, 8, 755. [CrossRef]

29. Rangel-Buitrago, N.; Neal, W.J.; de Jonge, V.N. Risk assessment as tool for coastal erosion management. Ocean Coast. Manag. 2020, 186, 105099. [CrossRef]

30. Koroglu, A.; Ranasinghe, R.; Jiménez, J.A.; Dastgheib, A. Comparison of Coastal Vulnerability Index applications for Barcelona Province. Ocean Coast. Manag. 2019, 178, 104799. [CrossRef]

31. De Serio, F.; Armenio, E.; Mossa, M.; Petrillo, A.F. How to define priorities in coastal vulnerability assessment. Geosciences 2018, 8 , 415. [CrossRef]

32. Pantusa, D.; D'Alessandro, F.; Riefolo, L.; Principato, F.; Tomasicchio, G.R. Application of a coastal vulnerability index. A case study along the Apulian Coastline, Italy. Water 2018, 10, 1218. [CrossRef]

33. Gornitz, V.M.; Daniels, R.C.; White, T.W.; Birdwell, K.R. The development of a coastal risk assessment database: Vulnerability to sea-level rise in the US Southeast. J. Coast. Res. 1994, 327-338.

34. Alexandrakis, G.; Poulos, S.E. An holistic approach to beach erosion vulnerability assessment. Sci. Rep. 2014, 4, 6078. [CrossRef]

35. Hamid, A.I.A.; Din, A.H.M.; Yusof, N.; Abdullah, N.M.; Omar, A.H.; Abdul Khanan, M.F. Coastal Vulnerability Index Development: A Review. ISPRS Arch. 2019, 42, 229-235. [CrossRef]

36. IPCC. Assessment of the Vulnerability of Coastal Areas to Sea Level Rise-A Common Methodology; National Institute for Coastal and Marine Management: The Hague, The Netherlands, 1991.

37. Özyurt, G.; Ergin, A. Improving coastal vulnerability assessments to sea-level rise: A new indicator-based methodology for decision makers. J. Coast. Res. 2010, 26, 265-273. [CrossRef]

38. Kantamaneni, K.; Rani, N.N.V.S.; Rice, L.; Sur, K.; Thayaparan, M.; Kulatunga, U.; Rege, R.; Yenneti, K.; Campos, L.C. A systematic review of coastal vulnerability assessment studies along Andhra Pradesh, India: A critical evaluation of data gathering, risk levels and mitigation strategies. Water 2019, 11,393. [CrossRef]

39. Mai, T.N.; Tran, D.Q.; Nguyen, T.H.H.; Luu, V.D.; Hoang, V.T.; Bui, T.T.; Pham, M.Q.; Tran, T.L.; Nguyen, H.Q.; Le, T.N.; et al. Vulnerability assessment of environment and natural resources in Vietnam coastal zone for sustainable use of natural resources, environment protection and adaptation to climate change (case study the Red River Delta coastal zone). VNU J. Sci. Earth Sci. 2011, 27, 161-173.

40. Boateng, I. GIS assessment of coastal vulnerability to climate change and coastal adaption planning in Vietnam. J. Coast. Conserv. 2012, 16, 25-36. [CrossRef]

41. Takagi, H.; Esteban, M.; Tran, T.T. Coastal Vulnerabilities in a Vietnamese Fast-growing City. In Coastal Disasters and Climate Change in Vietnam: Engineering and Planning Perspectives; Elsevier: Amsterdam, The Netherlands, 2012.

42. Bartlett, D.; Smith, J. GIS for Coastal Zone Management; CRC Press: Boca Raton, FL, USA, 2004.

43. Wright, D.J.; Barlett, D.J. Marine and Coastal Geographical Information Systems; CRC Press: Boca Raton, FL, USA, 1999.

44. Ruol, P.; Martinelli, L.; Favaretto, C. Vulnerability analysis of the Venetian littoral and adopted mitigation strategy. Water 2018, 10, 984. [CrossRef]

45. Inma, D.L. Littoral Cells. In Encyclopedia of Coastal Science; Charles W. Finkl, Ed.; Springer: Cham, Switzerland, $2005 ;$ p. 327.

46. Dang, K.B.; Dang, V.B.; Bui, Q.T.; Nguyen, V.V.; Pham, T.P.N.; Ngo, V.L. A Convolutional Neural Network for coast classification based on ALOS and NOAA satellite data. IEEE Access 2020, 8, 11824-11839. [CrossRef]

47. Hong Nguyen, P.; Cong Bui, Q.; Ha Vu, P.; The Pham, T. Scenario-based tsunami hazard assessment for the coast of Vietnam from the Manila Trench source. Phys. Earth Planet. Inter. 2014, 236, 95-108. [CrossRef]

48. Hanh, P.T.T.; Furukawa, M. Impact of sea level rise on coastal zone of Vietnam. Bull. Coll. os Cience Univ. tge Ryukyus 2007, 84, 45-59.

49. Nguyen, T.A.; Vu, D.A.; Vu, V.P.; Nguyen, N.T.; Pham, M.T.; Nguyen, T.T.H.; Le, T.H.; Nguyen, T.V.; Hoang, L.K.; Vu, T.D.; et al. Human ecological effects of tropical storms in the coastal area of Ky Anh (Ha Tinh, Vietnam). Environ. Dev. Sustain. 2017, 19, 745-767. [CrossRef]

50. Giuliani, S.; Bellucci, L.G.; Nhon, D.H. The Coast of Vietnam: Present Status and Future Challenges for Sustainable Development, 2nd ed.; Elsevier: Amsterdam, The Netherlands, 2019; ISBN 9780081008539.

51. Duong, L.; Dong, T. East Sea-Natural Resources in Vietnam. Eur. J. Eng. Technol. Res. 2019, 4, 65-69. [CrossRef]

52. Tran, H.D.; Ta, T.T.; Tran, T.T. Importance of Tien Yen Estuary (Northern Vietnam) for early-stage Nuchequula nuchalis (Temminck \& Schlegel, 1845). Chiang Mai Univ. J. Nat. Sci. 2016, 15, 67-76. [CrossRef] 
53. Le Nguyen, H.T.; Vo Luong, H.P. Erosion and deposition processes from field experiments of hydrodynamics in the coastal mangrove area of Can Gio, Vietnam. Oceanologia 2019, 61, 252-264. [CrossRef]

54. Djokic, D.; Ye, Z.; Dartiguenave, C. Arc Hydro Tools Overview; Version 2.0; Esri Water Resources Team: Redlands, CA, USA, 2011; p. 15.

55. Zhang, H.; Yao, Z.; Yang, Q.; Li, S.; Baartman, J.E.M.; Gai, L.; Yao, M.; Yang, X.; Ritsema, C.J.; Geissen, V. An integrated algorithm to evaluate flow direction and flow accumulation in flat regions of hydrologically corrected DEMs. Catena 2017, 151, 174-181. [CrossRef]

56. Lin, T.Y.; Goyal, P.; Girshick, R.; He, K.; Dollar, P. Focal Loss for Dense Object Detection. IEEE Trans. Pattern Anal. Mach. Intell. 2020, 42, 318-327. [CrossRef] [PubMed]

57. Ngo, V.L.; Dang, V.B.; Kinh, B.D.; Cgo, C.C. Coastal classification based on geological and geomorphological features for establishing the setback zone in Vietnam. J. Geol. 2020, 373, 160-175. (In Vietnamese)

58. Gulli, A.; Pal, S. Deep Learning with Keras-Implement neural networks with Keras on Theano and TensorFlow; Packt Publishing: Birmingham, UK, 2017; ISBN 9781787128422.

59. Wagner, F.H.; Sanchez, A.; Tarabalka, Y.; Lotte, R.G.; Ferreira, M.P.; Aidar, M.P.M.; Gloor, E.; Phillips, O.L.; Aragão, L.E.O.C. Using the U-net convolutional network to map forest types and disturbance in the Atlantic rainforest with very high resolution images. Remote Sens. Ecol. Conserv. 2019, 5, 360-375. [CrossRef]

60. Dang, K.B.; Dang, V.B.; Dang, T.T.H.; Ngo, C.C. Assessments of Sand Dune Ecosystem Service Potential from Son Tra (Da Nang) to Tam Ky (Quang Nam). VNU J. Sci. Earth Environ. Sci. 2020, 36, 81-92.

61. Nguyen, T.T.; Ngo, H.H.; Guo, W.; Nguyen, H.Q.; Luu, C.; Dang, K.B.; Liu, Y.; Zhang, X. New approach of water quantity vulnerability assessment using satellite images and GIS-based model: An application to a case study in Vietnam. Sci. Total Environ. 2020, 737, 139784. [CrossRef]

62. Fish, M.R.; Côté, I.M.; Horrocks, J.A.; Mulligan, B.; Watkinson, A.R.; Jones, A.P. Construction setback regulations and sea-level rise: Mitigating sea turtle nesting beach loss. Ocean Coast. Manag. 2008, 51, 330-341. [CrossRef]

63. Rochette, J.; Puy-Montbrun, G.; Wemaëre, M.; Billé, R. Coastal setback zones in the Mediterranean: A study on Article 8-2 of the Mediterranean ICZM Protocol. Biochim. Biophys. Acta 2010, 413, 26.

64. Blaschke, A.P.; Derx, J.; Zessner, M.; Kirnbauer, R.; Kavka, G.; Strelec, H.; Farnleitner, A.H.; Pang, L. Setback distances between small biological wastewater treatment systems and drinking water wells against virus contamination in alluvial aquifers. Sci. Total Environ. 2016, 573, 278-289. [CrossRef]

65. Escudero-Castillo, M.; Felix-Delgado, A.; Silva, R.; Mariño-Tapia, I.; Mendoza, E. Beach erosion and loss of protection environmental services in Cancun, Mexico. Ocean Coast. Manag. 2018, 156, 183-197. [CrossRef]

66. De Andrade, T.S.; Sousa, P.H.G.D.O.; Siegle, E. Vulnerability to beach erosion based on a coastal processes approach. Appl. Geogr. 2019, 102, 12-19. [CrossRef]

67. Güneralp, B.; Güneralp, I.; Liu, Y. Changing global patterns of urban exposure to flood and drought hazards. Glob. Environ. Chang. 2015, 31, 217-225. [CrossRef]

68. Titus, J.G.; Richman, C. Maps of lands vulnerble to sea level rise: Modeled elevations along the US Atlantic and Gulf coasts. Clim. Res. 2001, 18, 205-228. [CrossRef]

69. O'Carroll, S. Coastal Erosion and Shoreline Classification in Stratford, Prince Edward Island; 2010; p. 96. Available online: http: //www.gov.pe.ca/photos/original/erosionstrat.pdf (accessed on 17 January 2020).

70. Hanley, M.E.; Hoggart, S.P.G.; Simmonds, D.J.; Bichot, A.; Colangelo, M.A.; Bozzeda, F.; Heurtefeux, H.; Ondiviela, B.; Ostrowski, R.; Recio, M.; et al. Shifting sands? Coastal protection by sand banks, beaches and dunes. Coast. Eng. 2014, 87, 136-146. [CrossRef]

71. Wellman, E.; Sutton-Grier, A.; Imholt, M.; Domanski, A. Catching a wave? A case study on incorporating storm protection benefits into Habitat Equivalency Analysis. Mar. Policy 2017, 83, 118-125. [CrossRef]

72. Giardino, A.; Diamantidou, E.; Pearson, S.; Santinelli, G. A Regional Application of Bayesian Modeling for Coastal Erosion and Sand Nourishment Management. Water 2019, 11, 61. [CrossRef]

73. Plomaritis, T.A.; Costas, S.; Ferreira, Ó. Use of a Bayesian Network for coastal hazards, impact and disaster risk reduction assessment at a coastal barrier (Ria Formosa, Portugal). Coast. Eng. 2018, 134, 134-147. [CrossRef]

74. Arreguín-Sánchez, F.; Ruiz-Barreiro, T.M. Approaching a functional measure of vulnerability in marine ecosystems. Ecol. Indic. 2014, 45, 130-138. [CrossRef]

75. Jäger, W.S.; Christie, E.K.; Hanea, A.M.; den Heijer, C.; Spencer, T. A Bayesian network approach for coastal risk analysis and decision making. Coast. Eng. 2018, 134, 48-61. [CrossRef]

76. Nagai, K.; Kono, S.; Quang, D.X. Wave characteristics on the central coast of Vietnam in the South China Sea. Coast. Eng. J. 1998, 40, 347-366. [CrossRef]

77. Duc, D.M.; Tung, T.T.; McLaren, P.; Anh, T.N.; Thi Quynh, D. Sediment transport trends and cross-sectional stability of a lagoonal tidal inlet on the Central Coast of Vietnam. Int. J. Sediment Res. 2019, 34, 322-334. [CrossRef]

78. Dat Tran, T.; Truong Dinh, D.; Tri Doan, Q.; Tien Tran, Q. Applications of Numerical Modelling for the Study on Storm Surge in Typhoon Xangsane in the Central Coast of Vietnam. Trop. Cyclone Res. Rev. 2018, 7, 179-192. [CrossRef]

79. Barrett-Mold, C. The Influence of Morphological Evolution on Coastal Dune Plant Species Composition and Succession. Master's Thesis, University College London, London, UK, 2007. 
80. Willis, A.; Harris, P.J.; Rodrigues, B.F.; Sparks, T.H. Primary sand-dune plant community and soil properties during the west-coast India monsoon. Eur. J. Ecol. 2016, 2, 60-71. [CrossRef]

81. Barbier, E.; Hacker, S.; Kennedy, C.; Stier, A.; Silliman, B. The value of estuarine and coastal ecosystem services. Ecol. Monogr. 2011, 81, 169-193. [CrossRef]

82. Barman, N.; Paul, A.; Chatterjee, S.; Bera, G.; Kamila, A. Coastal Sand Dune Systems: Location, Formation, Morphological Characteristics Analysis through Vegetation Processes Estimation. J. Geogr. Environ. Earth Sci. Int. 2016, 4, 1-8. [CrossRef]

83. Barbier, E.B. Marine ecosystem services. Curr. Biol. 2017, 27, R507-R510. [CrossRef]

84. Lithgow, D.; Martínez, M.L.; Gallego-Fernández, J.B.; Silva, R.; Ramírez-Vargas, D.L. Exploring the co-occurrence between coastal squeeze and coastal tourism in a changing climate and its consequences. Tour. Manag. 2019, 74, 43-54. [CrossRef]

85. Trung Thanh, H.; Tschakert, P.; Hipsey, M.R. Moving up or going under? Differential livelihood trajectories in coastal communities in Vietnam. World Dev. 2021, 138, 105219. [CrossRef] 